ORP-56325

Revision 0

\title{
Final Report - Sulfate Solubility in RPP-WTP HLW Glasses, VSL-06R6780-1, Rev. 0
}

Prepared for the U.S. Department of Energy

Assistant Secretary for Environmental Management

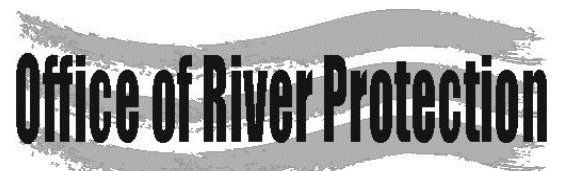

P.O. Box 450

Richland, Washington 99352 
ORP-56325

Revision 0

\section{Final Report - Sulfate Solubility in RPP-WTP HLW Glasses, VSL-06R6780-1, Rev. 0}

A. A. Kruger

Department of Energy - Office of River Protection

I. L. Pegg

The Catholic University of America

Z. Feng

The Catholic University of America
H. Gan

The Catholic University of America

W. K. Kot

The Catholic University of America

Date Published

June 2006

Prepared for the U.S. Department of Energy

Assistant Secretary for Environmental Management

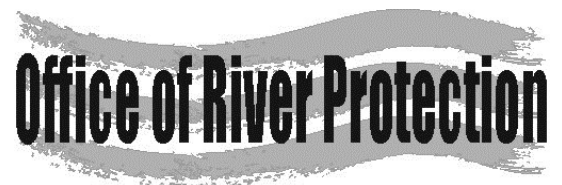

P.O. Box 450

Richland, Washington 99352

APPROVED

By Julia Raymer at 9:18 am, Dec 03, 2013

Release Approval

Date 
ORP-56325

Revision 0

TRADEMARK DISCLAIMER

Reference herein to any specific commercial product, process, or service by tradename, trademark, manufacturer, or otherwise, does not necessarily constitute or imply its endorsement, recommendation, or favoring by the United States Government or any agency thereof or its contractors or subcontractors.

This report has been reproduced from the best available copy.

Printed in the United States of America 
VSL-06R6780-1

\title{
Final Report
}

\section{Sulfate Solubility in RPP-WTP HLW Glasses}

\author{
prepared by
}

Wing K. Kot, Hao Gan, Zhijian Feng, and Ian L. Pegg

\author{
Vitreous State Laboratory \\ The Catholic University of America \\ Washington, DC 20064 \\ for \\ Duratek, Inc. \\ and \\ Bechtel National, Inc.
}

May 8, 2006

Rev. 0, 6/23/06 
Document Number and Revision: VSL-06R6780-1, Rev. 0

Issue Date:

June 23, 2006

Performing Organization: Vitreous State Laboratory, The Catholic University of America

Test Specifications:

Test Exceptions:

24590-HLW-TSP-RT-01-006, Rev. 1

Test Plans:

24590-HLW-TEF-RT-05-00007

R\&T Focus Area(s): $\quad$ HLW Waste Form Qualification

Test Scoping Statement(s): VSL-13

\section{Completeness of Testing:}

This report describes the results of work and testing specified by the above-listed Test Specifications, Test Plans, and Test Exceptions. The work and any associated testing followed established quality assurance requirements and were conducted as authorized. The descriptions provided in this report are an accurate account of both the conduct of the work and the data collected. Results required by the Test Plans are reported. Also reported are any unusual or anomalous occurrences that are different from the starting hypotheses. The test results and this report have been reviewed and verified.

I.L. Pegg:
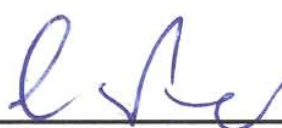

Date:

VSL Program Director/Principal Investigator

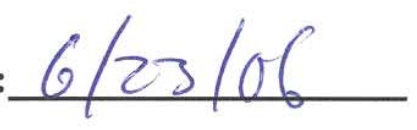

I. Joseph: Hmocend osefob Date: $6 / 23 / 06$ 


\section{TABLE OF CONTENTS}

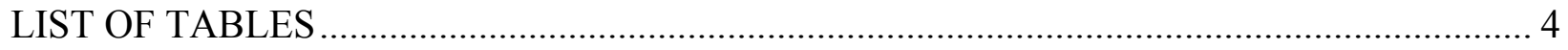

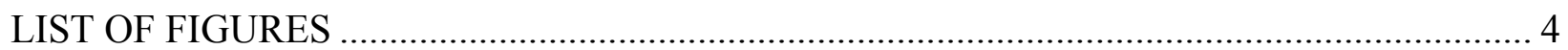

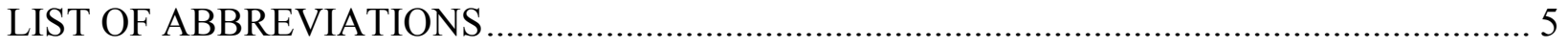

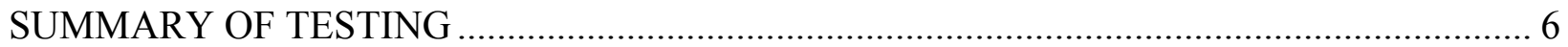

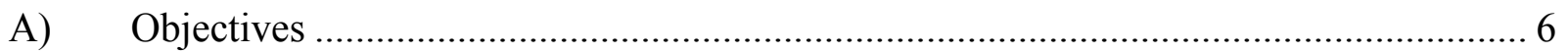

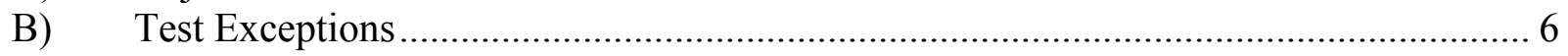

C) Results and Performance Against Success Criteria ............................................ 7

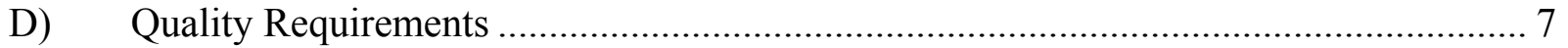

E) R\&T Test Conditions ................................................................................. 7

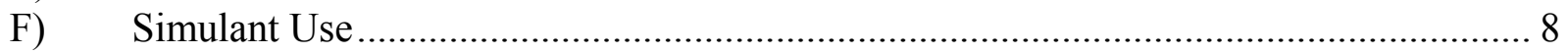

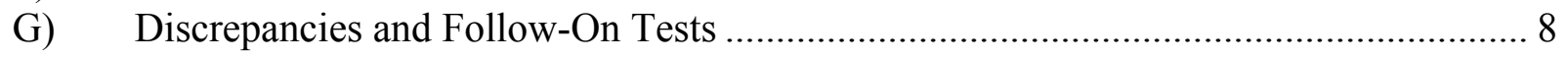

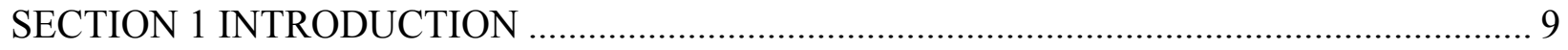

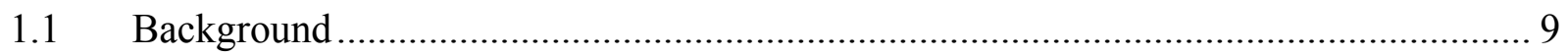

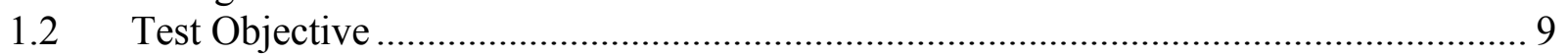

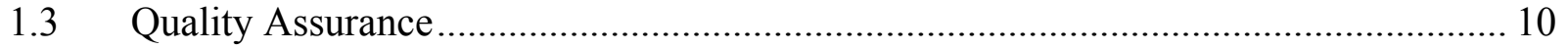

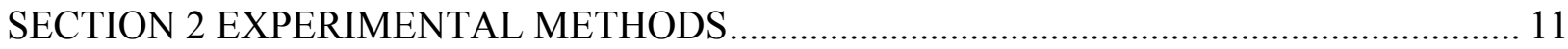

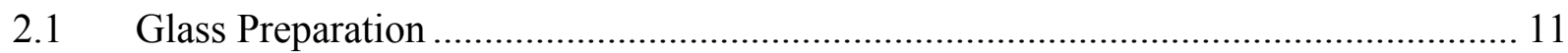

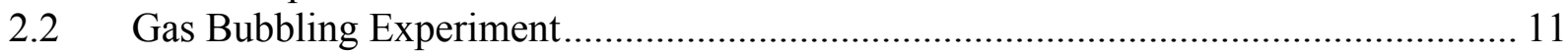

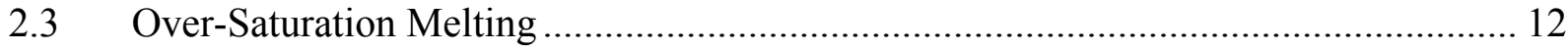

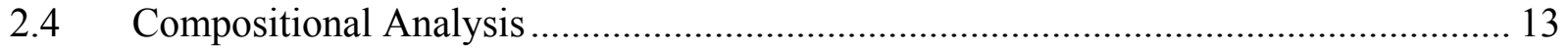

SECTION 3 SULFATE SOLUBILITY IN HLW GLASSES ............................................. 14

3.1 Sulfate Solubility Data ................................................................................ 14

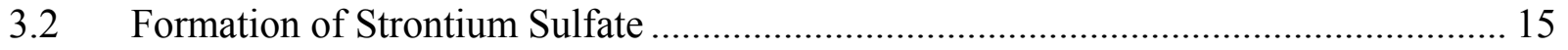

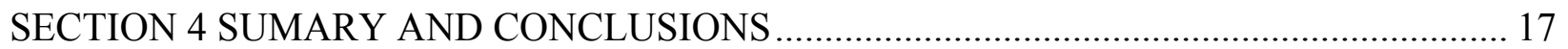

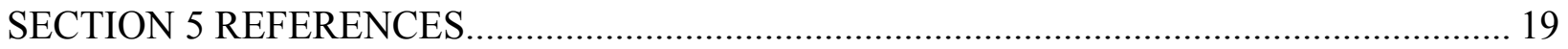




\section{LIST OF TABLES}

Table 3.1. Summary of HLW Glasses Selected for Sulfate Solubility Testing ................... 21

Table 3.2. $\quad$ Target Compositions of HLW Glasses Selected for Sulfate Solubility Testing .......... 22

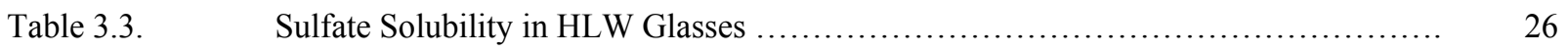

Table 3.4. Analytical Data of the Sulfate Salt Phases that Resulted from Over-Saturation of

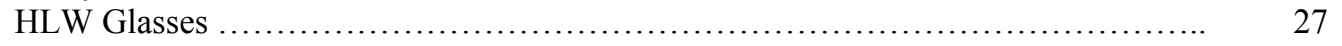

Table 3.5. Density and Melting Point of Selected Sulfate Salts ........................... 31

\section{LIST OF FIGURES}

Figure 3.1. Development of Saturation Plateau as the Glass Melt (HLW98-86) is Saturated with

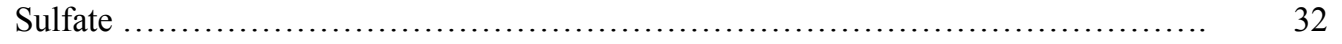

Figure 3.2. Sulfate Solubility in HLW Glasses as a Function of $\mathrm{Na}_{2} \mathrm{O}$ in Glass .................. 33

Figure 3.3. Scanning Electron Micrograph of an Inclusion that Developed and Segregated Inside HLW Glass (HLW06-24) after Bubbling Experiment ........................... 


\section{LIST OF ABBREVIATIONS}

$\begin{array}{ll}\text { AES } & \text { Atomic Emission Spectroscopy } \\ \text { ANL } & \text { Argonne National Laboratory } \\ \text { DCP } & \text { Direct Current Plasma } \\ \text { DWPF } & \text { Defense Waste Processing Facility } \\ \text { EA } & \text { Environmental Assessment } \\ \text { HLW } & \text { High Level Waste } \\ \text { IC } & \text { Ion Chromatography } \\ \text { LAW } & \text { Low Activity Waste } \\ \text { LRM } & \text { Low Activity Waste Reference Material } \\ \text { NIST } & \text { National Institute of Standards and Technology } \\ \text { NQA } & \text { Nuclear Quality Assurance } \\ \text { PVC } & \text { Poly-Vinyl Chloride } \\ \text { QA } & \text { Quality Assurance } \\ \text { QARD } & \text { Quality Assurance Requirements and Descriptions Document } \\ \text { RPP } & \text { River Protection Project } \\ \text { VSL } & \text { Vitreous State Laboratory } \\ \text { WTP } & \text { Hanford Tank Waste Treatment and Immobilization Plant } \\ \text { XRF } & \text { X-ray Fluorescence }\end{array}$




\section{SUMMARY OF TESTING}

\section{A) Objectives}

If the sulfate content in the waste feed is sufficiently high, it is possible for a separate molten sulfate salt phase to form on top of the glass melt in the RPP-WTP vitrification process. The formation of such a salt phase is undesirable from many perspectives and, in order to avoid its formation, it is important to know the solubility of sulfate in typical glass melts. In the WTP process, it was expected that most of the sulfate would be partitioned into the LAW waste streams, leaving the sulfate concentrations in the HLW waste feeds generally too low to pose significant phase separation problems. However, recent process models suggest that sulfate concentrations in HLW glasses may likely exceed the highest concentration tested in HLW crucible melts, and exceed values tested in scaled melter runs that showed segregated salt layers. Since the sulfate solubilities in typical HLW glass melts is not known, there is a need to collect such data to provide a metric to determine whether the newly projected sulfate concentrations in HLW feeds may need to be addressed through a more comprehensive program, as was the case for LAW glasses. Further, in view of the greater complexity and diversity of the HLW glass compositions, information is needed on the effects of HLW glass composition on the solubility of sulfate in order to begin to develop a rational basis to provide mitigation measures should there be the need to address the increased sulfate concentrations in HLW feeds. The objective of this work was to provide the first step in that direction.

\begin{tabular}{|l|l|l|}
\hline Test Objective & $\begin{array}{c}\text { Objective } \\
\text { Met }\end{array}$ & \multicolumn{1}{|c|}{ Discussion } \\
\hline $\begin{array}{l}\text { Conduct crucible-scale tests to } \\
\text { determine the sulfate solubilities in } \\
\text { HLW glasses. }\end{array}$ & Yes & $\begin{array}{l}\text { Twenty HLW glass formulations were selected from } \\
\text { previously developed and tested glasses. The selected } \\
\text { glasses were saturated with SO } \mathrm{O}_{3} \text { by bubbling a gaseous } \\
\text { mixture through the melts at 1150 }{ }^{\circ} \mathrm{C} \text { The sulfate } \\
\text { solubilities in the selected HLW glasses were } \\
\text { determined by analyzing the chemical compositions of } \\
\text { the glass melts in equilibrium with molten sulfate. The } \\
\text { results are discussed in Section 3. }\end{array}$ \\
\hline
\end{tabular}

\section{B) Test Exceptions}

A Test Exception (24590-HLW-TEF-RT-05-00007) was generated to address the testing described in this report. The resolution and test objective associated with that Test Exception is given above in Section A. 


\section{C) Results and Performance Against Success Criteria}

Twenty HLW glass formulations were selected from previously developed and tested glasses. Although many of the selected HLW glasses contained sulfate in their original formulations, the concentrations were uniformly low $(<0.28 \mathrm{wt} \%)$ and the equilibrium solubility limits in these glasses were unknown. In the present work, the solubility of sulfate in each of the $20 \mathrm{HLW}$ glasses selected was determined. The measured solubilities (of $\mathrm{SO}_{3}$ in glass) range from $0.53 \mathrm{wt} \%$ to $1.60 \mathrm{wt} \%$, with a median of $0.64 \mathrm{wt} \%$. These values are generally comparable to those found for typical LAW glasses. They also provide a better definition of the range of sulfate solubilities in typical HLW glass melts upon which future studies can expand, if necessary, to give a better understanding of how HLW glass compositions influence sulfate solubility.

It should be noted that these measurements relate to the solubility of sulfate in the selected melts, which is to be distinguished from the amount of sulfate allowable in the melter feed in order to prevent sulfate salt formation, which is typically lower. The former is a thermodynamic property whereas the latter also involves important kinetic effects, in addition to effects stemming from the generally more complex environment during actual melter processing and canister cooling.

\section{D) Quality Requirements}

This work was conducted under a quality assurance (QA) program compliant with NQA1 (1989) and NQA-2a (1990) subpart 2.7 and DOE/RW-0333P, Rev. 13, "Quality Assurance Requirements and Description" (QARD). This program is supplemented by a Quality Assurance Project Plan for RPP-WTP work performed at VSL. Test and procedure requirements by which the testing activities are planned and controlled are also defined in this plan. The program is supported by VSL standard operating procedures that were used for this work.

Glass preparation and glass compositional analysis are subject to QARD. All work in these areas was performed according to VSL QA programs and implementing procedures that are compliant with QARD.

\section{E) R\&T Test Conditions}

A review was conducted of HLW glass formulations that had previously been tested. Based on this, 20 glasses were selected for sulfate saturation testing in an effort to cover the range of expected HLW glass compositions. The selection of these glasses was approved by the WTP Project. Archived or freshly prepared glass samples were used in sulfate solubility tests. All $20 \mathrm{HLW}$ glass samples were tested using a method that loaded $\mathrm{SO}_{3}$ into the glass melts (at $1150^{\circ} \mathrm{C}$ ) by bubbling mixtures of $\mathrm{SO}_{2} / \mathrm{O}_{2} / \mathrm{N}_{2}$ through the melts. Periodic sampling and analysis, as the partial pressure of $\mathrm{SO}_{3}$ was gradually increased, provided data to follow the concentration of sulfate dissolved in glass from which the sulfate solubility in the selected HLW glass was determined as the saturation concentration. A second method was employed to measure the sulfate solubility in 5 of the $20 \mathrm{HLW}$ glasses selected. The method involved thoroughly mixing 
powdered glass samples ( -100 mesh) with excess reagent grade ammonium sulfate (which corresponded to $10 \mathrm{wt} \% \mathrm{SO}_{3}$ in glass) before melting the mixture at $1150^{\circ} \mathrm{C}$. The melt was then quenched and the glass washed free of salt phase before analysis to determine sulfate solubility.

Chemical compositions of the glasses were determined by X-ray fluorescence spectroscopy (XRF) on powdered glass samples. The segregated sulfate salt phase was dissolved in acid, before analysis by direct current plasma atomic emission spectroscopy (DCP-AES) and ion chromatography (IC) for common glass components and sulfate, respectively.

\section{F) Simulant Use}

All of the glasses produced at crucible scale at VSL were prepared from reagent grade chemicals in combinations designed to achieve the target compositions. These simulated glasses were based on either waste compositions provided by the WTP Project or matrices that were statistically designed to support development of property-composition models.

\section{G) Discrepancies and Follow-On Tests}

The draft of this report (VSL-06S6780-1, Rev. A) was issued for review and comment as a Data Summary Report. One of the review comments recommended that, since all the contents required for a Final Report were included in Rev. A, the report be changed to a Final Report in order to make the data reported herein available for wider uses. With the concurrence of the Project, after comment resolution and incorporation of the appropriate responses, the current revision of the report is issued as a Final Report (VSL-06R6780-1, Rev. 0).

There were no discrepancies in these tests.

If the flow-sheet projections of increased sulfate content in the HLW feeds persist, considerable additional work will be required to address the mitigation of sulfate salt formation during HLW vitrification, as was the case for LAW vitrification. That work should include a more comprehensive investigation of the effect of HLW glass composition on sulfate solubility, and melter tests to determine the operational boundaries at which salt formation occurs. These results would form the basis for the establishment of compositional process control limits to prevent salt formation.

Because of the relatively high content of $\mathrm{SrO}$ in some HLW glasses, formation of $\mathrm{SrSO}_{4}$ in the segregated salt phase has been observed with some of the selected glasses. Because of its higher density, it may be possible to form salt phases that, rather than float on the top of the glass melt, may sink to the bottom of the melter. Pooling and collection of such a phase could present heretofore unforeseen risks with respect to potential penetration of the salt phase into the melter refractories and discharge into the glass product. Further testing is recommended to address this concern. 


\section{SECTION 1 INTRODUCTION}

\subsection{Background}

The Low Activity Waste (LAW) tanks that are scheduled to provide the River Protection Project-Hanford Tank Waste Treatment and Immobilization Plant (RPP-WTP) with waste feeds contain significant amounts of sulfate. The sulfate content in the LAW feeds is sufficiently high that a separate molten sulfate salt phase may form on top of the glass melt during the vitrification process. Since the formation of the salt phase is undesirable from many perspectives, mitigation approaches need to be developed. Considerable progress has been made and reported by the Vitreous State Laboratory (VSL) in enhancing sulfate incorporation into LAW glass melts and developing strategies to manage and mitigate the risk associated with high-sulfate feeds [1-6].

In contrast, little work has been performed on High Level Waste (HLW) glasses to investigate the behavior of sulfate during vitrification. This is primarily because sulfate is usually present in the HLW waste feed at relatively low concentration, according to available inventory data, and sulfate has not been expected to pose problems as a component that limits waste loading. However, recent process models suggest that sulfate concentrations in HLW glasses may likely exceed the highest concentrations tested in HLW crucible melts, and exceed values tested in scaled melter runs that showed segregated salt layers [7]. This is not surprising since todate, based on the above expectations, the concentrations of sulfate tested in both HLW crucible melts and melter tests have been low: the maximum sulfate concentration in HLW glasses formulated to support melter tests is $0.13 \mathrm{wt} \%$ (as $\mathrm{SO}_{3}$ ) [8] (one set of melter tests was performed with a target HLW glass formulated to support actual waste testing, which has a $\mathrm{SO}_{3}$ concentration of $0.19 \mathrm{wt} \%[9,10])$, whereas HLW matrix glasses, designed to cover a much wider glass compositional region, contain a maximum of only $0.28 \mathrm{wt} \%$ of $\mathrm{SO}_{3}$ [11]. Since the range of sulfate solubilities in typical HLW glass melts is not known, there is a need to collect such data to provide a metric to determine whether the newly projected sulfate concentrations in HLW feeds may need to be addressed through a more comprehensive program, as was the case for LAW glasses. Further, in view of the greater complexity and diversity of the HLW glass compositions, information is needed on the effect of HLW glass composition on the solubility of sulfate in order to begin to develop a rational basis to provide mitigation measures should there be the need to address the increased sulfate concentrations in HLW feeds. The objective of this work was to provide the first step in that direction.

\section{$1.2 \quad$ Test Objective}

This report is responsive to the Test Specification [12], Test Plan [13], and Test Exception [7], for HLW glass property-composition modeling. The primary objective was to select and test a series of HLW glasses to cover the compositional range of HLW glasses to be 
produced at the WTP. Crucible-scale tests were conducted to determine the sulfate solubilities in these glasses. The results will be used to plan further testing, if found necessary.

\subsection{Quality Assurance}

This work was conducted under a quality assurance program compliant with NQA-1 (1989) and NQA-2a (1990) subpart 2.7, and the Quality Assurance Requirements and Description (QARD) Document (DOE/RW-0333P, Rev. 13) [14]. This program is supplemented by a Quality Assurance Project Plan for RPP-WTP work performed at VSL [15]. Test and procedure requirements by which the testing activities are planned and controlled are also defined in that plan. The program is supported by VSL standard operating procedures that were used for this work [16].

The following specific areas of this work are also subject to the QARD: glass preparation and glass compositional analysis. All work in these areas was performed according to VSL QA programs and implementing procedures that are compliant with QARD. 


\section{SECTION 2 \\ EXPERIMENTAL METHODS}

This section provides a description of the experimental methods and equipment that were used at VSL to prepare and characterize the selected glasses. The test methods are described in detail in controlled technical procedures that are part of the VSL QA program [16].

\subsection{Glass Preparation}

Glasses were prepared from reagent grade or higher purity chemicals to produce a batch size of approximately 400 grams of glass according to VSL standard operating procedures [17]. Crucible melts were prepared by melting the appropriate combination of well-mixed chemicals at $1150^{\circ} \mathrm{C}$ for 120 minutes in a platinum or platinum-gold crucible. Mixing of the melt was accomplished with a platinum stirrer, beginning 15 minutes after the furnace temperature reached $1150^{\circ} \mathrm{C}$ and continuing for the next 100 minutes. The molten glass was poured onto a graphite plate to cool, and the resulting glass was then processed and distributed for analyses and sulfate solubility testing.

\subsection{Gas Bubbling Experiment}

The sulfate solubility $\left(1150^{\circ} \mathrm{C}\right)$ in the selected HLW glass melt was determined experimentally by analyzing the chemical composition of the glass melt in equilibrium with molten sulfate at the designated test temperature. During the experiment, $\mathrm{SO}_{3}$ was loaded into the glass melt gradually via bubbling a gaseous mixture of $\mathrm{SO}_{2}, \mathrm{O}_{2}$, and $\mathrm{N}_{2}$ through the molten glass. The partial pressure of $\mathrm{SO}_{3}\left(\mathrm{P}_{\mathrm{SO}_{3}}\right)$ was controlled through the chemical reaction between $\mathrm{SO}_{2}$ and $\mathrm{O}_{2}$ at the test temperature in the presence of a catalyst (the platinum bubbling tube). Gases were mixed, and the flow was regulated using a gas proportioner with the flow tubes calibrated for each individual gas stream. The mixed gas was then transported through flexible polyvinyl chloride (PVC) tubing fitted to a Pt bubbling tube, the other end of which was immersed in the molten glass. The flow rate of the mixed gas was $30 \mathrm{ml} / \mathrm{min}$ (at room temperature).

For each of the sulfate saturation experiments by gas bubbling, 100 grams of test glass was placed in a 200-ml Pt crucible and covered by a Pt sheet furnished with a slot for introducing the gas bubbling tubes. The crucible was then loaded in the center of the platform of a Del-Tech furnace preheated to $1150^{\circ} \mathrm{C}$. The gas mixture was introduced through the roof of the furnace, passing through preheated Pt tubes (24 to 36 inches in length). For each prescribed gas mixture of controlled $\mathrm{P}_{\mathrm{SO}_{3}}$, the test glass melt was bubbled continuously for 3.5 hours. At the end of each bubbling period, the setup was removed from the furnace for inspection for the development of a sulfate layer, and sampling ( $\approx 3-5$ grams). A complete bubbling experiment usually involved 6 to 9 bubbling cycles, with step-wise increased $\mathrm{P}_{\mathrm{SO}_{3}}$. Two to three more bubbling cycles would be 
normally conducted after onset of sulfate layer to ensure saturation (see Section 3.1). Sulfate salt was sampled at the end of the bubbling experiment.

At sufficiently high temperatures and gas flow rates, it is possible to perturb the melt composition due to the preferential evaporation of the more volatile constituents (e.g., As, Sb, B). However, examination of the more volatile components in the present glass compositions (e.g., $\mathrm{As}_{2} \mathrm{O}_{5}$ and $\mathrm{Sb}_{2} \mathrm{O}_{3}$ ) before and after bubbling tests revealed no detectable changes, indicating that this was not an issue under the present test conditions. Boron was not analyzed by $\mathrm{x}$-ray fluorescence (XRF) spectroscopy, but previous experience with refractory corrosion tests in such melts, which were conducted at a higher temperature $\left(1200^{\circ} \mathrm{C}\right)$ and much longer durations (6 days), indicated that the loss of boron was negligible (analyses in those cases were performed by direct current plasma-atomic emission spectroscopy (DCP-AES)). Consequently, compositional changes due to evaporation during the present tests are considered insignificant.

One of the technical necessities for determining sulfate solubility in silicate glass by means of bulk analysis (e.g., XRF) is to remove any separated sulfate salt from the glass in order to produce a homogeneous sample for analysis. Glasses sampled from gas-bubbling experiments, especially in the oversaturated condition, contain numerous inclusions of sulfate salt that are finely dispersed inside the glass. Consequently, care must be exercised to separate the sulfate inclusions from the bulk glass. The glass samples collected at the end of each bubbling cycle were powdered $(<75$ mesh) and then washed to remove possible inclusions of segregated sulfate salt prior to analysis by XRF for chemical composition. The solvents used for washing included dilute $(0.75 \mathrm{wt} \%) \mathrm{HNO}_{3}$ to remove alkali and calcium sulfates, $\mathrm{NaCl}(14 \mathrm{wt} \%)$ solution to remove strontium sulfate, and finally de-ionized water. The salt samples were analyzed by DCP-AES and ion chromatography (IC) for chemical composition (see Section 2.4).

\subsection{Over-Saturation Melting}

The sulfate solubility in a subset of the selected glasses was also measured by an alternative method, which involved simple over-batching with sulfate. The selected HLW glasses were powdered to give -100 mesh samples. About $20 \mathrm{~g}$ of each sample was thoroughly mixed with reagent grade ammonium sulfate $\left(\left(\mathrm{NH}_{4}\right)_{2} \mathrm{SO}_{4}\right)$. The amount of $\left(\mathrm{NH}_{4}\right)_{2} \mathrm{SO}_{4}$ used was equivalent to $10 \mathrm{wt} \%$ of $\mathrm{SO}_{3}$ in glass if all $\mathrm{S}$ was retained in the glass. The glass $/\left(\mathrm{NH}_{4}\right)_{2} \mathrm{SO}_{4}$ mixture was loaded into a $\mathrm{Pt} / \mathrm{Au}$ crucible $(50 \mathrm{ml})$ with cover and re-melted at $1150^{\circ} \mathrm{C}$ for 2 hours. At the end of 2 hours, the crucible was quenched in water and the glass removed for examination. Washing of the glass chunks to remove all salt phases was followed by grinding (-200 mesh) and then washing of the glass powder to ensure removal of all sulfate salts. Analysis of $\mathrm{SO}_{3}$ in the washed and powdered glass sample provided an estimate of sulfate solubility of the HLW glass.

The use of $\left(\mathrm{NH}_{4}\right)_{2} \mathrm{SO}_{4}$ instead of other sulfates (e.g., $\mathrm{Na}_{2} \mathrm{SO}_{4}$ ) has the advantage of minimizing the effect on the original glass composition since its decomposition results in volatile ammonia. Thermal decomposition of $\left(\mathrm{NH}_{4}\right)_{2} \mathrm{SO}_{4}$ in the presence of zinc and other oxides has been developed as a means of recovery of ammonia and sulfate [18]. 


\subsection{Compositional Analysis}

With the exception of the lightest elements (i.e., boron and lithium), all glass components including $\mathrm{SO}_{3}$ were measured by XRF. Test glasses were powdered to give -200 mesh samples before analyses with an ARL 9400 wavelength dispersive XRF spectrometer. The XRF is calibrated over a range of glass compositions using standard reference materials traceable to NIST as well as other glasses, including the Argonne National Laboratory-Low-Activity Waste Reference Material (ANL-LRM), Defense Waste Processing Facility-Environmental Assessment (DWPF-EA) glass, West Valley Reference 6 glass, and RPP-WTP HLW and LAW glasses.

The analyses of sulfate salts were performed with DCP-AES and IC. Samples of the sulfate phase removed from saturated glass samples were subjected to microwave assisted total acid dissolution in Teflon vessels according to VSL standard operating procedures. Twenty milliliters of a 1:5 mixture of concentrated $\mathrm{HF}: \mathrm{HNO}_{3}$ was diluted to $50 \mathrm{ml}$ for use in dissolution. The sample solution was analyzed by DCP-AES. Sulfate in the solution was measured by IC (Dionex DX-120 and IonPac AS14) and reported herein as $\mathrm{SO}_{3}$. 


\section{SECTION 3 SULFATE SOLUBILITY IN HLW GLASSES}

A total of twenty HLW glasses was selected for the sulfate solubility study. As directed by the Test Exception [7], these glasses were selected in an effort to cover the range of expected HLW glass compositions. The WTP Project approved the glasses selected before testing started. All of the selected glasses have been formulated and tested previously to support a variety of tasks including melter tests, actual waste tests, and property-composition model development [8, 9, 11, 19]. Table 3.1 summarizes the selected glasses while Table 3.2 provides their target compositions before testing for sulfate solubility.

Table 3.1 shows that the majority of the glasses (15 out of 20) were selected from various matrices designed to support development of HLW property-composition models [11, 19]. These matrices were designed using a layered approach to cover an outer-layer region of HLW glass compositions that were more extreme but still feasible, as well as an inner-layer region of HLW glass compositions that were less extreme but more likely to be produced at the WTP. It is seen in Table 3.2 that the selected matrix glasses cover a considerably wider compositional region than that covered by the glasses formulated to support melter and actual waste tests. For example, the $\mathrm{Na}_{2} \mathrm{O}$ content, which is known to play a significant role in determining sulfate solubility [1-6], in the selected matrix glasses ranges from $3.7 \mathrm{wt} \%$ to $20.0 \mathrm{wt} \%$, compared with $10.8-12.6 \mathrm{wt} \%$ found in the HLW98-xx and HLW04-xx glasses [8, 9]. The last glass selected, HLW-ALG-03 (from a series tested to verify the HLW glass formulation algorithm) [20], also has a relatively high $\mathrm{Na}_{2} \mathrm{O}$ content $(18.97 \mathrm{wt} \%)$.

The concentrations of $\mathrm{SO}_{3}$ in the selected glasses before the sulfate saturation experiments are generally low and, with the exception of 2 glasses (HLW06-22 and -24), are limited to $0.1 \mathrm{wt} \%$.

\subsection{Sulfate Solubility Data}

Gas bubbling experiments were conducted on each of the 20 HLW glasses selected, with periodic sampling/analysis of the resulting glass, and examination for appearance of sulfate salt as an indication of sulfate saturation. The $\mathrm{SO}_{3}$ concentration in the glass (as measured after bubbling and washing to remove any separated sulfate salt phase, see Section 2.2) corresponding to onset of sulfate salt separation was taken as the solubility of the sulfate salt in the glass melt. The saturation points thus determined were further checked by analysis of $\mathrm{SO}_{3}$ concentrations in glasses before and after the suspected saturation points. A plateau in plots of concentration of $\mathrm{SO}_{3}$ in glass melts vs. the partial pressure of $\mathrm{SO}_{3}$ in coexisting gas phase confirmed the saturation of a $\mathrm{SO}_{3}$-containing phase under the experimental conditions. Figure 3.1 presents an example of how the saturation plateau develops as a glass melt (HLW98-86) is gradually saturated with sulfate from $0 \mathrm{wt} \%$ (i.e., the target $\mathrm{SO}_{3}$ concentration in HLW98-86 glass before bubbling, see Table 3.2) as the partial pressure of $\mathrm{SO}_{3}$ is increased. The sulfate solubility in 
HLW98-86 is estimated from the plot to be $0.73 \mathrm{wt} \%$ (of $\mathrm{SO}_{3}$ in glass). Table 3.3 lists the solubility of sulfate in $20 \mathrm{HLW}$ glasses measured by the gas bubbling method. Sulfate solubility in 5 of the $20 \mathrm{HLW}$ glasses was also determined by melting after addition of large excess of ammonium sulfate; the results are also presented in Table 3.3 for comparison.

It can be seen in Table 3.3 that the sulfate solubility data, measured by gas bubbling, range from $0.53 \mathrm{wt} \%\left(\mathrm{SO}_{3}\right.$ in glass) to $1.60 \mathrm{wt} \%$, with a median value of $0.64 \mathrm{wt} \%$. After exclusion of the outlier at $1.60 \mathrm{wt} \%$, the average solubility is $0.70 \mathrm{wt} \%$. These results are, in general, similar to the solubility data found for the LAW glasses [5], despite the fact that the LAW data involve many more glasses, including some with rather dissimilar compositions. While not perfect, there is a generally satisfactory agreement between the data obtained by gas bubbling and the data obtained by melting with excess batched sulfate, including the unusually high solubility in HLW06-22.

When the HLW glass melt under test was becoming saturated with sulfate during the bubbling experiment, formation of a sulfate-rich phase that segregated from the glass melt was invariably observed. The salt phase was separated from the glass by dissolution and analyzed. The results are given in Table 3.4. As observed with LAW glasses [2], sodium is typically the major counter-ion in these salts, typically followed by lithium. This is especially important for LAW vitrification because, on an oxide basis, sodium is also the major component in the LAW stream. Thus, while sodium tends to reduce the activity of $\mathrm{SO}_{3}$ in the melt (thereby increasing its solubility), it also tends to promote salt formation. These competing effects can lead to nonmonotonic dependence of sulfate solubility on sodium concentration [1]. Figure 3.2 relates the measured sulfate solubility with the $\mathrm{Na}_{2} \mathrm{O}$ content in the selected glasses. No simple correlation is apparent in Figure 3.2. Similar plots show no obvious relationships between sulfate solubility and $\mathrm{Li}_{2} \mathrm{O}$ or total alkali. While it is likely that these trends are still present, they may not be evident in such plots due to the effects of other composition variables. Simple regression analysis of the sulfate solubility vs. glass composition showed that much of the variation $\left(\mathrm{R}^{2} \sim 0.83\right)$ can be accounted for by $\mathrm{Li}_{2} \mathrm{O}, \mathrm{B}_{2} \mathrm{O}_{3}, \mathrm{Na}_{2} \mathrm{O}, \mathrm{SrO}$, and $\mathrm{SiO}_{2}$ (with relative regression coefficients of $\sim 13,3,3,2$, and -2 , respectively). It is clear from Table 3.4 that, in addition to sodium, lithium and strontium also show considerable affinity for the salt phase. While these trends seem generally reasonable in comparison to results for LAW glasses, considerably more data are needed to make such relationships useful.

\subsection{Formation of Strontium Sulfate}

As noted above, significant amounts of strontium sulfate were found in many of the salt samples (Table 3.4). It is noted that strontium appears to prefer sulfate to silicate: for example, a HLW glass (HLW02-50) with $1.5 \mathrm{wt} \%$ of $\mathrm{SrO}$ is found to be in equilibrium with a salt phase that contains over $5 \mathrm{wt} \%$ of $\mathrm{SrO}(\mathrm{SrO}$ is used here for convenient comparison, and it is not implied that $\mathrm{Sr}$ is present as $\mathrm{SrO}$ in the salt phase). More than $17 \mathrm{wt} \% \mathrm{SrO}$ is present in the sulfate salt phase from saturation of the glass HLW06-22, which has a target glass composition of about $10 \mathrm{wt} \% \mathrm{SrO}$ (see Tables 3.2 and 3.4). It is apparent that, when it is present, strontium from the HLW glasses constitutes one of the major components in the segregated sulfate-rich salt phase. 
This represents a distinct and potentially important difference from the situation with LAW glasses, which contain no strontium.

Table 3.5 lists the density and melting point of selected crystalline sulfates. Of the sulfates listed, strontium sulfate has the highest melting point and density, both by a wide margin. As a result of the considerably higher melting point, the eutectic melting point between $\mathrm{Li}$-Sr sulfate is about $150^{\circ} \mathrm{C}$ higher than that between Li-Na sulfate $\left(750^{\circ} \mathrm{C}\right.$ versus $\left.\approx 600^{\circ} \mathrm{C}\right)$. It is probable that the large difference in the melting points (and presumably in densities) between the alkali sulfate and Sr-rich sulfate melts would facilitate formation of a separate Sr-rich sulfate phase, especially if local over-saturation occurs during melting. An important potential consequence of the high density of strontium sulfate is that, it may be possible to form salt phases that, rather than float on top of the glass melt, may sink to the bottom of the melter. Pooling and collection of such a phase could present heretofore unforeseen risks with respect to potential penetration into the melter refractories and discharge into the glass product. Figure 3.3 shows the formation of Sr-containing sulfate inclusions within the glass quenched from melts. It is likely that the higher density played a role in the less complete segregation into a salt-phase layer on top of a glass-phase layer than is the case when strontium is not present. 


\section{SECTION 4 SUMARY AND CONCLUSIONS}

Twenty HLW glasses were selected to provide representative coverage of the expected compositional range of glasses to be produced at the WTP. All of the selected glasses were previously formulated and characterized to support various tasks including melter testing, actual waste testing, property-composition model development, and support of HLW glass algorithm development. The solubility of sulfate in these glasses was measured by saturation with $\mathrm{SO}_{3}$ by continuous gas bubbling. The measured sulfate solubilities $\left(\mathrm{SO}_{3}\right.$ in glass) range from $0.53 \mathrm{wt} \%$ to $1.60 \mathrm{wt} \%$, with a median of $0.64 \mathrm{wt} \%$. The sulfate solubilities in five of the selected glasses were also determined using a second method employing over-batching with ammonium sulfate. These results generally showed reasonable agreement with those obtained by the gas bubbling method.

Overall, the sulfate solubility data obtained for the HLW glasses are similar in magnitude to those for LAW glasses. Although the data set shows no clear trends when plotted versus sodium, lithium, or total alkali content, regression analysis suggests that lithium, sodium, and strontium are amongst the most influential composition variables. However, a better understanding of compositional dependence of sulfate solubility will require more data from systematic studies. Analysis of the sulfate salt phases that formed from these glasses showed that, in addition to sodium, lithium and strontium also show considerable affinity for the salt phase.

Because of the relatively high contents of $\mathrm{SrO}$ in some HLW glasses, formation of $\mathrm{SrSO}_{4}$ in the segregated salt phase has been observed with some of the selected glasses. Because of its higher density, it may be possible to form salt phases that, rather than float on top of the glass melt, may sink to the bottom of the melter. Pooling and collection of such a phase could present heretofore unforeseen risks with respect to potential penetration into the melter refractories and discharge into the glass product. Consequently, further testing is recommended to address this concern.

It should be noted that all of the measurements reported in the present work relate to the solubility of sulfate in the selected melts, which is to be distinguished from the amount of sulfate allowable in the melter feed in order to prevent sulfate salt formation, which is typically lower. The former is a thermodynamic property whereas the latter also involves important kinetic effects in addition to effects stemming from the generally more complex environment during actual melter processing.

If the flow-sheet projections of increased sulfate content in the HLW feeds persist, sulfate formation during HLW vitrification will become an important issue, as was the case for LAW vitrification. Considerable additional work will then be required to address the mitigation of sulfate salt formation. That work should include a more comprehensive and systematic investigation of the effect of HLW glass composition on sulfate solubility, and melter tests to 
determine the operational boundaries at which salt formation occurs. These results would form the basis for the establishment of compositional process control limits to prevent salt formation. Although the general testing strategy employed for LAW should be applicable, there are both significant differences between the LAW and HLW feeds as well as considerably greater compositional diversity within the HLW feeds. Some of the issues that such a test program should consider include:

- Sulfate solubility across the current HLW composition region.

- The limits of salt formation in melter tests across the current HLW composition region.

- The effects of other variables, such as bubbling rate, feed water content, glass production rate, and redox (resulting primarily from nitrate/nitrite and organic concentrations).

- Effects of increased sulfate content on materials corrosion rates and especially bubbler lifetime.

- Sulfate partitioning to the off-gas.

- Sulfate separation during canister cooling, which could compromise product quality.

- Sulfate separation during idling or due to loss of a bubbler.

- Determination of operating limits based on above test results, including revised qualified glass composition region.

- Impact of sulfate on achievable waste loadings and, therefore, waste treatment rates and canisters counts. 


\section{SECTION 5 REFERENCES}

[1] Pegg, I. L., Gan, H., Muller, I. S., McKeown, D. A., and Matlack, K. S., "Preliminary Results on Enhanced Sulfate Incorporation During Vitrification of LAW Feeds," Interim Report, VSL-00R3630-1, Rev. 1, Vitreous State Laboratory, The Catholic University of America, Washington, D. C., April 5, 2000.

[2] Muller, I. S., Buechele, A. C., and Pegg, I. L., "Glass Formulation and Testing with RPPWTP LAW Simulants," Final Report, VSL-00R3560-2, Rev. 0, Vitreous State Laboratory, The Catholic University of America, Washington, D. C., February 23, 2001.

[3] Matlack, K. S., Morgan, S. P., and Pegg, I. L., "Melter Tests with LAW Envelope B Simulants to Support Enhanced Sulfate Incorporation," VSL-00R3501-1, Rev. 0, Vitreous State Laboratory, The Catholic University of America, Washington, D.C., November 27, 2000 .

[4] Matlack, K. S., Morgan, S. P., and Pegg, I. L., "Melter Tests with LAW Envelope A and C Simulants to Support Enhanced Sulfate Incorporation," VSL-01R3501-2, Rev. 0, Vitreous State Laboratory, The Catholic University of America, Washington, D.C., January 26, 2001.

[5] Muller, I. S. and Pegg, I. L., "Baseline LAW Glass Formulation Testing," Final Report, VSL-03R3460-1, Rev. 0, Vitreous State Laboratory, The Catholic University of America, Washington, D. C., August 5, 2003.

[6] Muller, I. S., Diener, G., Joseph, I., and Pegg, I. L., "Proposed Approach for Development of LAW Glass Formulation Correlation," VSL-04L4460-1, Rev. 2, Vitreous State Laboratory, The Catholic University of America, Washington, D. C., October 29, 2004.

[7] Vienna, J. D., "WTP Test Exception, 24590-HLW-TEF-RT-05-00007, River Protection Projection Project, Waste Treatment Plan, Richland, WA, October 12, 2005.

[8] Kot, W. K., Klatt, K., and Pegg, I. L., "Glass Formulation to Support Melter Runs with HLW Simulants," Final Report, VSL-03R3760-2, Rev. 0, Vitreous State Laboratory, The Catholic University of America, Washington, D. C., September 30, 2003.

[9] Kot, W. K. and Pegg, I. L., "HLW Glass Formulation to Support C-106/AY-102 Actual Waste Testing," Final Report, VSL-04R4770-1, Rev. 0, Vitreous State Laboratory, The Catholic University of America, Washington, D. C., August 12, 2004. 
[10] Matlack, K. S., Gong, W., Tevfik, B., D’Angelo, N., Brandys, M., Kot, W. K., and Pegg, I. L., "Integrated DM1200 Melter Testing Using AZ-102 and C-106/AY-102 HLW Simulants: HLW Simulant Verification," Final Report, VSL-05R5800-1, Rev. 0, Vitreous State Laboratory, The Catholic Universtiy of America, Washington, D. C., June 27, 2005.

[11] Kot, W. K., Gan, H., and Pegg, I. L., "Preparation and Testing (T1\% and PCT) of HLW Matrix Glasses to Support WTP Property-Composition Model Development," Final Report, VSL-05R5780-2, Rev. 0, V Vitreous State Laboratory, The Catholic University of America, Washington, D. C., October 12, 2005.

[12] Swanberg, D. J., "HLW Glass Property-Composition Modeling," BNI Test Specification, 24590-HLW-TSP-RT-01-006, Rev. 1, River Protection Project, Waste Treatment Plant, Richland, WA, November 27, 2001.

[13] Gan, H. and I. L. Pegg,. "HLW Glass Property Composition Modeling," Test Plan, VSL02T7800-1, Rev. 1, Vitreous State Laboratory, The Catholic University of America, Washington, D.C., April 16, 2002.

[14] DOE/RW-0333P, “Quality Assurance Requirements and Description (QARD),” Rev.13, Department of Energy, Office of Civilian Radioactive Waste Management, Washington D.C., 2004.

[15] VSL, "Quality Assurance Project Plan for RPP-WTP Support Activities Conducted by VSL," QAPP Rev. 6 (and earlier revisions), Vitreous State Laboratory, The Catholic University of America, Washington, D. C., November 12, 2003.

[16] VSL, "Master List of Controlled VSL Manuals and Standard Operating Procedures in Use," QA-MLCP, Rev. 15 (and earlier revisions), Vitreous State Laboratory, The Catholic University of America, Washington, D. C., June 6, 2005.

[17] Vitreous State Laboratory, "Crucible Melts," Technical Procedure, TPI-CM, Rev. 2 (and earlier revisions), Vitreous State Laboratory, The Catholic University of America, Washington, D. C., August 10, 2004.

[18] Dugger, G. L., Adams, J. B., and Bart, R., “Ammonium Sulfate Decomposition,” U. S. Atomic Energy Commission Report, RMO-2036, International Minerals and Chemical Corporation, Chicago, IL, February 28, 1955.

[19] Kot, W. K., Klatt, K., Gan, H., Pegg, I. L., Cooley, S. K., Piepel, G. F., and Bates, D. J., "Regulatory Testing of RPP-WTP HLW Glass to Support Delisting Compliance," Final Report, VSL-04R4780-1, Rev. 0, Vitreous State Laboratory, The Catholic University of America, Washington, D. C., September 30, 2004.

[20] Perez, J., to Pegg, I. L., "High-Level Waste Glass Formulation Algorithm Verification Testing Guidance," CCN 127601, River Protection Project, Waste Treatment Plant, Richland, WA, January 3, 2006. 
Table 3.1. Summary of HLW Glasses Selected for Sulfate Solubility Testing.

\begin{tabular}{|c|c|c|}
\hline Glass ID & Description & Reference \\
\hline HLW98-77 & AZ-101 glass formulated to support melter tests & [8] \\
\hline HLW98-86 & $\begin{array}{l}\text { AZ-102 (with Sr/TRU products) glass formulated to support } \\
\text { melter tests }\end{array}$ & [8] \\
\hline HLW98-96 & C-104/AY-101 glass formulated to support melter tests & [8] \\
\hline HLW02-15 & \multirow{4}{*}{$\begin{array}{l}\text { Initial Matrix (outer layer) glasses designed to support } \\
\text { development of property-composition models }\end{array}$} & \multirow{4}{*}{ [19] } \\
\hline HLW02-22 & & \\
\hline HLW02-24 & & \\
\hline HLW02-26 & & \\
\hline HLW02-43 & \multirow{3}{*}{$\begin{array}{l}\text { Initial Matrix (inner layer) glasses designed to support } \\
\text { development of property-composition models }\end{array}$} & \multirow{3}{*}{ [19] } \\
\hline HLW02-46 & & \\
\hline HLW02-50 & & \\
\hline HLW03-01 & \multirow{2}{*}{$\begin{array}{l}\text { Augmentation Matrix (outer layer) glasses designed to support } \\
\text { development of property-composition models }\end{array}$} & \multirow{2}{*}[19]{} \\
\hline HLW03-03 & & \\
\hline HLW04-07S1 & $\begin{array}{l}\text { Based on glass HLW04-07, which was designed to support } \\
\text { C-106/AY-102 actual waste tests }\end{array}$ & [9] \\
\hline HLW06-16 & $\begin{array}{l}\text { Spinel Matrix (inner layer) glass designed to support } \\
\text { development of property-composition models }\end{array}$ & [11] \\
\hline HLW06-22 & \multirow{5}{*}{$\begin{array}{l}\text { Spinel Matrix (outer layer) glasses designed to support } \\
\text { development of property-composition models }\end{array}$} & \multirow{5}{*}[11]{} \\
\hline HLW06-24 & & \\
\hline HLW06-27 & & \\
\hline HLW06-29 & & \\
\hline HLW06-32 & & \\
\hline HLW-ALG-03 & HLW glass tested to verify HLW glass formulation algorithm & [20] \\
\hline
\end{tabular}


Table 3.2. Target Compositions of HLW Glasses Selected for Sulfate Solubility Testing.

\begin{tabular}{|c|c|c|c|c|c|}
\hline Oxide & HLW98-77 & HLW98-86 & HLW98-96 ${ }^{(b)}$ & HLW02-15 & HLW02-22 \\
\hline $\mathrm{Ag}_{2} \mathrm{O}$ & $0.02 \%$ & $0.15 \%$ & $0.03 \%$ & $0.20 \%$ & $0.02 \%$ \\
\hline $\mathrm{Al}_{2} \mathrm{O}_{3}$ & $5.20 \%$ & $5.29 \%$ & $3.36 \%$ & $8.50 \%$ & $8.50 \%$ \\
\hline $\mathrm{As}_{2} \mathrm{O}_{3}$ & - $^{\text {(a) }}$ & $0.19 \%$ & - & $0.23 \%$ & $0.02 \%$ \\
\hline $\mathrm{B}_{2} \mathrm{O}_{3}$ & $11.91 \%$ & $9.39 \%$ & $10.10 \%$ & $14.00 \%$ & $14.00 \%$ \\
\hline $\mathrm{BaO}$ & - & - & - & $0.30 \%$ & $0.03 \%$ \\
\hline $\mathrm{Bi}_{2} \mathrm{O}_{3}$ & - & - & - & $0.01 \%$ & $0.01 \%$ \\
\hline $\mathrm{CaO}$ & $0.28 \%$ & $0.30 \%$ & $0.45 \%$ & $0.50 \%$ & $0.50 \%$ \\
\hline $\mathrm{CdO}$ & $0.06 \%$ & - & - & $0.05 \%$ & $0.05 \%$ \\
\hline $\mathrm{Ce}_{2} \mathrm{O}_{3}$ & - & - & - & $0.05 \%$ & $0.05 \%$ \\
\hline $\mathrm{Cl}$ & - & $0.11 \%$ & - & $0.20 \%$ & $0.20 \%$ \\
\hline $\mathrm{CoO}$ & - & - & - & $0.01 \%$ & $0.01 \%$ \\
\hline $\mathrm{Cr}_{2} \mathrm{O}_{3}$ & - & $0.08 \%$ & $0.06 \%$ & $0.20 \%$ & $0.02 \%$ \\
\hline $\mathrm{Cs}_{2} \mathrm{O}$ & - & - & - & $0.01 \%$ & $0.01 \%$ \\
\hline $\mathrm{CuO}$ & $0.03 \%$ & $0.04 \%$ & $0.03 \%$ & $0.10 \%$ & $0.01 \%$ \\
\hline $\mathrm{F}$ & $0.04 \%$ & - & $0.11 \%$ & $0.05 \%$ & $0.05 \%$ \\
\hline $\mathrm{Fe}_{2} \mathrm{O}_{3}$ & $12.22 \%$ & $12.56 \%$ & $8.95 \%$ & $14.00 \%$ & $9.50 \%$ \\
\hline $\mathrm{K}_{2} \mathrm{O}$ & $0.03 \%$ & - & - & $0.06 \%$ & $0.06 \%$ \\
\hline $\mathrm{La}_{2} \mathrm{O}_{3}$ & $0.41 \%$ & $0.24 \%$ & $0.15 \%$ & $0.30 \%$ & $0.30 \%$ \\
\hline $\mathrm{Li}_{2} \mathrm{O}$ & $3.53 \%$ & $3.01 \%$ & $3.09 \%$ & $2.00 \%$ & $6.00 \%$ \\
\hline $\mathrm{MgO}$ & $0.11 \%$ & $1.17 \%$ & - & $0.12 \%$ & $0.12 \%$ \\
\hline $\mathrm{MnO}$ & $0.17 \%$ & $3.99 \%$ & $1.42 \%$ & $4.69 \%$ & $0.00 \%$ \\
\hline $\mathrm{Na}_{2} \mathrm{O}$ & $11.66 \%$ & $11.84 \%$ & $10.74 \%$ & $12.54 \%$ & $4.00 \%$ \\
\hline $\mathrm{Nd}_{2} \mathrm{O}_{3}$ & $0.31 \%$ & $0.15 \%$ & $0.10 \%$ & - & - \\
\hline $\mathrm{NiO}$ & $0.61 \%$ & $0.17 \%$ & $0.44 \%$ & $0.10 \%$ & $0.10 \%$ \\
\hline $\mathrm{P}_{2} \mathrm{O}_{5}$ & - & $0.09 \%$ & $0.04 \%$ & $0.50 \%$ & $0.50 \%$ \\
\hline $\mathrm{PbO}$ & $0.03 \%$ & $0.14 \%$ & $0.11 \%$ & $0.40 \%$ & $0.04 \%$ \\
\hline $\mathrm{PdO}$ & - & - & - & $0.12 \%$ & $0.12 \%$ \\
\hline $\mathrm{Rh}_{2} \mathrm{O}_{3}$ & - & - & - & $0.05 \%$ & $0.05 \%$ \\
\hline $\mathrm{RuO}_{2}$ & - & - & - & $0.08 \%$ & $0.08 \%$ \\
\hline $\mathrm{SO}_{3}$ & $0.08 \%$ & - & - & $0.10 \%$ & $0.10 \%$ \\
\hline $\mathrm{Sb}_{2} \mathrm{O}_{3}$ & - & $0.26 \%$ & - & $0.02 \%$ & $0.20 \%$ \\
\hline $\mathrm{SeO}_{2}$ & - & $0.37 \%$ & - & $0.20 \%$ & $0.20 \%$ \\
\hline $\mathrm{SiO}_{2}$ & $47.45 \%$ & $47.07 \%$ & $43.32 \%$ & $37.99 \%$ & $53.00 \%$ \\
\hline $\mathrm{SnO}_{2}$ & - & - & - & - & - \\
\hline $\mathrm{SrO}$ & $0.03 \%$ & $0.92 \%$ & - & $0.00 \%{ }^{(\mathrm{c})}$ & $0.08 \%$ \\
\hline $\mathrm{TeO}_{2}$ & - & - & - & $0.01 \%$ & $0.01 \%$ \\
\hline $\mathrm{ThO}_{2}$ & - & - & $4.05 \%$ & $0.00 \%$ & $0.00 \%$ \\
\hline $\mathrm{TiO}_{2}$ & - & $0.14 \%$ & $0.02 \%$ & $0.03 \%$ & $0.03 \%$ \\
\hline $\mathrm{Tl}_{2} \mathrm{O}$ & - & - & - & $0.19 \%$ & $0.02 \%$ \\
\hline $\mathrm{UO}_{3}$ & - & - & $2.57 \%$ & $0.00 \%$ & $0.00 \%$ \\
\hline $\mathrm{V}_{2} \mathrm{O}_{5}$ & - & - & - & $0.10 \%$ & $0.01 \%$ \\
\hline $\mathrm{ZnO}$ & $2.02 \%$ & $2.07 \%$ & $2.02 \%$ & $2.00 \%$ & $2.00 \%$ \\
\hline $\mathrm{ZrO}_{2}$ & $3.81 \%$ & $0.26 \%$ & $8.84 \%$ & $0.00 \%$ & $0.00 \%$ \\
\hline TOTAL & $100.0 \%$ & $100.0 \%$ & $100.0 \%$ & $100.0 \%$ & $100.0 \%$ \\
\hline
\end{tabular}

(a) — indicates empty data field.

(b) Composition is different than that given in Reference [8] because of revised oxide forms (e.g., $\mathrm{UO}_{3}$ used instead of $\mathrm{UO}_{2}$ ).

(c) A value of $0.00 \%$ indicates that the oxide is part of the matrix design but the oxide is absent from the selected glass. 
Table 3.2. Target Compositions of HLW Glasses Selected for Sulfate Solubility Testing (continued).

\begin{tabular}{|c|c|c|c|c|c|}
\hline Oxide & HLW02-24 & HLW02-26 & HLW02-43 & HLW02-46 & HLW02-50 \\
\hline $\mathrm{Ag}_{2} \mathrm{O}$ & $0.15 \%$ & $0.20 \%$ & $0.04 \%$ & $0.04 \%$ & $0.04 \%$ \\
\hline $\mathrm{Al}_{2} \mathrm{O}_{3}$ & $8.50 \%$ & $4.00 \%$ & $6.50 \%$ & $5.50 \%$ & $6.00 \%$ \\
\hline $\mathrm{As}_{2} \mathrm{O}_{3}$ & $0.18 \%$ & $0.23 \%$ & $0.05 \%$ & $0.05 \%$ & $0.05 \%$ \\
\hline $\mathrm{B}_{2} \mathrm{O}_{3}$ & $5.00 \%$ & $5.00 \%$ & $13.00 \%$ & $9.15 \%$ & $13.00 \%$ \\
\hline $\mathrm{BaO}$ & $0.23 \%$ & $0.30 \%$ & $0.06 \%$ & $0.06 \%$ & $0.06 \%$ \\
\hline $\mathrm{Bi}_{2} \mathrm{O}_{3}$ & $0.01 \%$ & $0.01 \%$ & $0.01 \%$ & $0.01 \%$ & $0.01 \%$ \\
\hline $\mathrm{CaO}$ & $0.50 \%$ & $0.50 \%$ & $0.50 \%$ & $0.50 \%$ & $0.50 \%$ \\
\hline $\mathrm{CdO}$ & $0.05 \%$ & $1.50 \%$ & $1.00 \%$ & $0.50 \%$ & $0.50 \%$ \\
\hline $\mathrm{Ce}_{2} \mathrm{O}_{3}$ & $0.05 \%$ & $0.05 \%$ & $0.05 \%$ & $0.05 \%$ & $0.05 \%$ \\
\hline $\mathrm{Cl}$ & $0.20 \%$ & $0.20 \%$ & $0.20 \%$ & $0.20 \%$ & $0.20 \%$ \\
\hline $\mathrm{CoO}$ & $0.01 \%$ & $0.01 \%$ & $0.01 \%$ & $0.01 \%$ & $0.01 \%$ \\
\hline $\mathrm{Cr}_{2} \mathrm{O}_{3}$ & $0.15 \%$ & $0.20 \%$ & $0.04 \%$ & $0.04 \%$ & $0.04 \%$ \\
\hline $\mathrm{Cs}_{2} \mathrm{O}$ & $0.01 \%$ & $0.01 \%$ & $0.01 \%$ & $0.01 \%$ & $0.01 \%$ \\
\hline $\mathrm{CuO}$ & $0.08 \%$ & $0.10 \%$ & $0.02 \%$ & $0.02 \%$ & $0.02 \%$ \\
\hline $\mathrm{F}$ & $0.05 \%$ & $0.05 \%$ & $0.05 \%$ & $0.05 \%$ & $0.05 \%$ \\
\hline $\mathrm{Fe}_{2} \mathrm{O}_{3}$ & $8.00 \%$ & $12.50 \%$ & $10.00 \%$ & $10.00 \%$ & $12.00 \%$ \\
\hline $\mathrm{K}_{2} \mathrm{O}$ & $0.06 \%$ & $0.06 \%$ & $0.06 \%$ & $0.06 \%$ & $0.06 \%$ \\
\hline $\mathrm{La}_{2} \mathrm{O}_{3}$ & $0.30 \%$ & $0.30 \%$ & $0.30 \%$ & $0.30 \%$ & $0.30 \%$ \\
\hline $\mathrm{Li}_{2} \mathrm{O}$ & $2.00 \%$ & $2.00 \%$ & $2.50 \%$ & $3.70 \%$ & $2.50 \%$ \\
\hline $\mathrm{MgO}$ & $0.12 \%$ & $0.12 \%$ & $0.12 \%$ & $0.12 \%$ & $0.12 \%$ \\
\hline $\mathrm{MnO}$ & $5.00 \%$ & $4.96 \%$ & $3.50 \%$ & $3.50 \%$ & $1.50 \%$ \\
\hline $\mathrm{Na}_{2} \mathrm{O}$ & $12.20 \%$ & $15.00 \%$ & $12.45 \%$ & $9.00 \%$ & $9.82 \%$ \\
\hline $\mathrm{Nd}_{2} \mathrm{O}_{3}$ & - $^{\text {(a) }}$ & - & - & - & - \\
\hline $\mathrm{NiO}$ & $0.10 \%$ & $0.10 \%$ & $0.30 \%$ & $0.80 \%$ & $0.30 \%$ \\
\hline $\mathrm{P}_{2} \mathrm{O}_{5}$ & $0.50 \%$ & $0.50 \%$ & $0.50 \%$ & $0.50 \%$ & $0.50 \%$ \\
\hline $\mathrm{PbO}$ & $0.31 \%$ & $0.40 \%$ & $0.08 \%$ & $0.08 \%$ & $0.08 \%$ \\
\hline $\mathrm{PdO}$ & $0.12 \%$ & $0.12 \%$ & $0.12 \%$ & $0.12 \%$ & $0.12 \%$ \\
\hline $\mathrm{Rh}_{2} \mathrm{O}_{3}$ & $0.05 \%$ & $0.05 \%$ & $0.05 \%$ & $0.05 \%$ & $0.05 \%$ \\
\hline $\mathrm{RuO}_{2}$ & $0.08 \%$ & $0.08 \%$ & $0.08 \%$ & $0.08 \%$ & $0.08 \%$ \\
\hline $\mathrm{SO}_{3}$ & $0.10 \%$ & $0.10 \%$ & $0.10 \%$ & $0.10 \%$ & $0.10 \%$ \\
\hline $\mathrm{Sb}_{2} \mathrm{O}_{3}$ & $0.02 \%$ & $0.02 \%$ & $0.15 \%$ & $0.05 \%$ & $0.15 \%$ \\
\hline $\mathrm{SeO}_{2}$ & $0.20 \%$ & $0.02 \%$ & $0.05 \%$ & $0.15 \%$ & $0.05 \%$ \\
\hline $\mathrm{SiO}_{2}$ & $47.05 \%$ & $37.99 \%$ & $41.00 \%$ & $49.00 \%$ & $43.53 \%$ \\
\hline $\mathrm{SnO}_{2}$ & - & - & - & - & - \\
\hline $\mathrm{SrO}$ & $5.00 \%$ & $5.00 \%$ & $3.50 \%$ & $1.50 \%$ & $1.50 \%$ \\
\hline $\mathrm{TeO}_{2}$ & $0.01 \%$ & $0.01 \%$ & $0.01 \%$ & $0.01 \%$ & $0.01 \%$ \\
\hline $\mathrm{ThO}_{2}$ & $0.00 \%{ }^{(\mathrm{b})}$ & $0.00 \%$ & $0.00 \%$ & $0.00 \%$ & $0.00 \%$ \\
\hline $\mathrm{TiO}_{2}$ & $0.03 \%$ & $0.03 \%$ & $0.03 \%$ & $0.03 \%$ & $0.03 \%$ \\
\hline $\mathrm{Tl}_{2} \mathrm{O}$ & $0.02 \%$ & $0.19 \%$ & $0.05 \%$ & $0.14 \%$ & $0.14 \%$ \\
\hline $\mathrm{UO}_{3}$ & $0.00 \%$ & $0.00 \%$ & $0.00 \%$ & $0.00 \%$ & $0.00 \%$ \\
\hline $\mathrm{V}_{2} \mathrm{O}_{5}$ & $0.08 \%$ & $0.10 \%$ & $0.02 \%$ & $0.02 \%$ & $0.02 \%$ \\
\hline $\mathrm{ZnO}$ & $2.00 \%$ & $2.00 \%$ & $2.00 \%$ & $2.00 \%$ & $2.00 \%$ \\
\hline $\mathrm{ZrO}_{2}$ & $1.50 \%$ & $6.00 \%$ & $1.50 \%$ & $2.50 \%$ & $4.50 \%$ \\
\hline TOTAL & $100.0 \%$ & $100.0 \%$ & $100.0 \%$ & $100.0 \%$ & $100.0 \%$ \\
\hline
\end{tabular}

(a) — indicates empty data field.

(b) A value of $0.00 \%$ indicates that the oxide is part of the matrix design but the oxide is absent from the selected glass. 
Table 3.2. Target Compositions of HLW Glasses Selected for Sulfate Solubility Testing (continued).

\begin{tabular}{|c|c|c|c|c|c|}
\hline Oxide & HLW03-01 & HLW03-03 & HLW04-07S1 & HLW06-16 & HLW06-22 \\
\hline $\mathrm{Ag}_{2} \mathrm{O}$ & $0.20 \%$ & $0.02 \%$ & - - & $0.10 \%$ & $0.10 \%$ \\
\hline $\mathrm{Al}_{2} \mathrm{O}_{3}$ & $8.34 \%$ & $1.95 \%$ & $4.90 \%$ & $10.00 \%$ & $13.00 \%$ \\
\hline $\mathrm{As}_{2} \mathrm{O}_{3}$ & $0.23 \%$ & $0.02 \%$ & - & - & - \\
\hline $\mathrm{B}_{2} \mathrm{O}_{3}$ & $13.73 \%$ & $4.88 \%$ & $10.29 \%$ & $6.50 \%$ & $15.00 \%$ \\
\hline $\mathrm{BaO}$ & $0.30 \%$ & $0.03 \%$ & $0.07 \%$ & $0.10 \%$ & $0.00 \%$ \\
\hline $\mathrm{Bi}_{2} \mathrm{O}_{3}$ & $0.01 \%$ & $0.01 \%$ & - & $0.30 \%$ & $0.30 \%$ \\
\hline $\mathrm{CaO}$ & $0.50 \%$ & $0.50 \%$ & $0.46 \%$ & $0.32 \%$ & $0.00 \%$ \\
\hline $\mathrm{CdO}$ & $0.05 \%$ & $1.60 \%$ & - & $0.24 \%$ & $1.65 \%$ \\
\hline $\mathrm{Ce}_{2} \mathrm{O}_{3}$ & $0.05 \%$ & $0.05 \%$ & $0.10 \%$ & - & - \\
\hline $\mathrm{Cl}$ & $0.20 \%$ & $0.20 \%$ & - & $0.20 \%$ & $0.20 \%$ \\
\hline $\mathrm{CoO}$ & $0.01 \%$ & $0.01 \%$ & - & - & - \\
\hline $\mathrm{Cr}_{2} \mathrm{O}_{3}$ & $0.02 \%$ & $0.49 \%$ & $0.22 \%$ & $0.25 \%$ & $0.60 \%$ \\
\hline $\mathrm{Cs}_{2} \mathrm{O}$ & $0.01 \%$ & $0.01 \%$ & $0.00 \%$ & - & - \\
\hline $\mathrm{CuO}$ & $0.10 \%$ & $0.01 \%$ & - & - & - \\
\hline $\mathrm{F}$ & $0.05 \%$ & $0.05 \%$ & - & $0.44 \%$ & $0.44 \%$ \\
\hline $\mathrm{Fe}_{2} \mathrm{O}_{3}$ & $13.73 \%$ & $13.68 \%$ & $14.05 \%$ & $7.00 \%$ & $1.40 \%$ \\
\hline $\mathrm{K}_{2} \mathrm{O}$ & $0.06 \%$ & $0.06 \%$ & - & $0.52 \%$ & $0.00 \%$ \\
\hline $\mathrm{La}_{2} \mathrm{O}_{3}$ & $0.30 \%$ & $0.30 \%$ & $0.08 \%$ & $0.18 \%$ & $1.23 \%$ \\
\hline $\mathrm{Li}_{2} \mathrm{O}$ & $5.88 \%$ & $2.68 \%$ & $2.65 \%$ & $3.00 \%$ & $6.01 \%$ \\
\hline $\mathrm{MgO}$ & $0.12 \%$ & $0.12 \%$ & $0.15 \%$ & $0.37 \%$ & $0.00 \%$ \\
\hline $\mathrm{MnO}$ & $6.08 \%$ & $6.84 \%$ & $2.83 \%$ & $1.75 \%$ & $0.00 \%$ \\
\hline $\mathrm{Na}_{2} \mathrm{O}$ & $3.92 \%$ & $10.76 \%$ & $12.57 \%$ & $20.00 \%$ & $6.84 \%$ \\
\hline $\mathrm{Nd}_{2} \mathrm{O}_{3}$ & - $^{\text {(a) }}$ & - & - & $0.33 \%$ & $0.80 \%$ \\
\hline $\mathrm{NiO}$ & $0.10 \%$ & $0.98 \%$ & $0.41 \%$ & $1.00 \%$ & $0.00 \%$ \\
\hline $\mathrm{P}_{2} \mathrm{O}_{5}$ & $0.50 \%$ & $0.50 \%$ & $0.56 \%$ & $0.50 \%$ & $0.50 \%$ \\
\hline $\mathrm{PbO}$ & $0.40 \%$ & $0.04 \%$ & $0.54 \%$ & $0.29 \%$ & $0.00 \%$ \\
\hline $\mathrm{PdO}$ & $0.12 \%$ & $0.12 \%$ & - & $0.12 \%$ & $0.12 \%$ \\
\hline $\mathrm{Rh}_{2} \mathrm{O}_{3}$ & $0.05 \%$ & $0.05 \%$ & - & $0.05 \%$ & $0.05 \%$ \\
\hline $\mathrm{RuO}_{2}$ & $0.08 \%$ & $0.08 \%$ & - & $0.13 \%$ & $0.13 \%$ \\
\hline $\mathrm{SO}_{3}$ & $0.10 \%$ & $0.10 \%$ & - & $0.04 \%$ & $0.28 \%$ \\
\hline $\mathrm{Sb}_{2} \mathrm{O}_{3}$ & $0.02 \%$ & $0.02 \%$ & - & - & - \\
\hline $\mathrm{SeO}_{2}$ & $0.20 \%$ & $0.20 \%$ & - & - & - \\
\hline $\mathrm{SiO}_{2}$ & $35.30 \%$ & $35.17 \%$ & $47.84 \%$ & $35.00 \%$ & $34.56 \%$ \\
\hline $\mathrm{SnO}_{2}$ & - & - & $0.06 \%$ & - & - \\
\hline $\mathrm{SrO}$ & $0.00 \%^{(\mathrm{b})}$ & $9.77 \%$ & $0.17 \%$ & $1.47 \%$ & $10.29 \%$ \\
\hline $\mathrm{TeO}_{2}$ & $0.01 \%$ & $0.01 \%$ & - & - & - \\
\hline $\mathrm{ThO}_{2}$ & $2.76 \%$ & $0.00 \%$ & - & $1.50 \%$ & $0.00 \%$ \\
\hline $\mathrm{TiO}_{2}$ & $0.03 \%$ & $0.03 \%$ & - & $0.32 \%$ & $0.00 \%$ \\
\hline $\mathrm{Tl}_{2} \mathrm{O}$ & $0.31 \%$ & $0.31 \%$ & - & - & - \\
\hline $\mathrm{UO}_{3}$ & $0.00 \%$ & $0.00 \%$ & - & $4.00 \%$ & $6.50 \%$ \\
\hline $\mathrm{V}_{2} \mathrm{O}_{5}$ & $0.10 \%$ & $0.01 \%$ & - & - & - \\
\hline $\mathrm{ZnO}$ & $3.06 \%$ & $1.95 \%$ & $1.03 \%$ & $2.50 \%$ & $0.00 \%$ \\
\hline $\mathrm{ZrO}_{2}$ & $2.98 \%$ & $6.40 \%$ & $0.99 \%$ & $1.50 \%$ & $0.00 \%$ \\
\hline TOTAL & $100.0 \%$ & $100.0 \%$ & $100.0 \%$ & $100.0 \%$ & $100.0 \%$ \\
\hline
\end{tabular}

(a) — indicates empty data field.

(b) A value of $0.00 \%$ indicates that the oxide is part of the matrix design but the oxide is absent from the selected glass. 
Table 3.2. Target Compositions of HLW Glasses Selected for Sulfate Solubility Testing (continued).

\begin{tabular}{|c|c|c|c|c|c|}
\hline Oxide & HLW06-24 & HLW06-27 & HLW06-29 & HLW06-32 & HLW-ALG-03 \\
\hline $\mathrm{Ag}_{2} \mathrm{O}$ & $0.10 \%$ & $0.10 \%$ & $0.10 \%$ & $0.10 \%$ & $0.05 \%$ \\
\hline $\mathrm{Al}_{2} \mathrm{O}_{3}$ & $13.00 \%$ & $1.88 \%$ & $1.88 \%$ & $1.88 \%$ & $1.93 \%$ \\
\hline $\mathrm{As}_{2} \mathrm{O}_{3}$ & - $^{\text {(a) }}$ & - & - & - & - \\
\hline $\mathrm{B}_{2} \mathrm{O}_{3}$ & $4.30 \%$ & $9.82 \%$ & $4.30 \%$ & $15.00 \%$ & $8.62 \%$ \\
\hline $\mathrm{BaO}$ & $0.30 \%$ & $0.00 \%$ & $0.30 \%$ & $0.00 \%$ & $0.04 \%$ \\
\hline $\mathrm{Bi}_{2} \mathrm{O}_{3}$ & $0.30 \%$ & $0.30 \%$ & $0.30 \%$ & $0.30 \%$ & - \\
\hline $\mathrm{CaO}$ & $1.00 \%$ & $0.00 \%$ & $1.00 \%$ & $0.00 \%$ & $0.34 \%$ \\
\hline $\mathrm{CdO}$ & $1.65 \%$ & $0.00 \%$ & $0.00 \%$ & $0.00 \%$ & - \\
\hline $\mathrm{Ce}_{2} \mathrm{O}_{3}$ & - & - & - & - & $0.05 \%$ \\
\hline $\mathrm{Cl}$ & $0.20 \%$ & $0.20 \%$ & $0.20 \%$ & $0.20 \%$ & - \\
\hline $\mathrm{CoO}$ & - & - & - & - & - \\
\hline $\mathrm{Cr}_{2} \mathrm{O}_{3}$ & $0.00 \%{ }^{(\mathrm{b})}$ & $0.00 \%$ & $0.00 \%$ & $0.60 \%$ & $0.50 \%$ \\
\hline $\mathrm{Cs}_{2} \mathrm{O}$ & - & - & - & - & - \\
\hline $\mathrm{CuO}$ & - & - & - & - & - \\
\hline $\mathrm{F}$ & $0.44 \%$ & $0.44 \%$ & $0.44 \%$ & $0.44 \%$ & $0.03 \%$ \\
\hline $\mathrm{Fe}_{2} \mathrm{O}_{3}$ & $1.40 \%$ & $1.40 \%$ & $15.00 \%$ & $15.00 \%$ & $12.65 \%$ \\
\hline $\mathrm{K}_{2} \mathrm{O}$ & $1.64 \%$ & $0.00 \%$ & $1.64 \%$ & $0.00 \%$ & $0.13 \%$ \\
\hline $\mathrm{La}_{2} \mathrm{O}_{3}$ & $1.23 \%$ & $0.00 \%$ & $0.00 \%$ & $0.00 \%$ & $0.10 \%$ \\
\hline $\mathrm{Li}_{2} \mathrm{O}$ & $0.00 \%$ & $6.01 \%$ & $6.01 \%$ & $0.00 \%$ & $3.06 \%$ \\
\hline $\mathrm{MgO}$ & $1.17 \%$ & $0.00 \%$ & $1.17 \%$ & $0.00 \%$ & $0.10 \%$ \\
\hline $\mathrm{MnO}$ & $0.00 \%$ & $0.00 \%$ & $0.00 \%$ & $8.00 \%$ & $2.10 \%$ \\
\hline $\mathrm{Na}_{2} \mathrm{O}$ & $16.25 \%$ & $3.70 \%$ & $3.70 \%$ & $20.00 \%$ & $18.97 \%$ \\
\hline $\mathrm{Nd}_{2} \mathrm{O}_{3}$ & $0.80 \%$ & $0.25 \%$ & $0.25 \%$ & $0.25 \%$ & $0.09 \%$ \\
\hline $\mathrm{NiO}$ & $0.00 \%$ & $0.00 \%$ & $0.00 \%$ & $0.00 \%$ & $1.00 \%$ \\
\hline $\mathrm{P}_{2} \mathrm{O}_{5}$ & $0.50 \%$ & $0.50 \%$ & $0.50 \%$ & $0.50 \%$ & $0.10 \%$ \\
\hline $\mathrm{PbO}$ & $0.91 \%$ & $0.00 \%$ & $0.91 \%$ & $0.00 \%$ & $0.21 \%$ \\
\hline $\mathrm{PdO}$ & $0.12 \%$ & $0.12 \%$ & $0.12 \%$ & $0.12 \%$ & - \\
\hline $\mathrm{Rh}_{2} \mathrm{O}_{3}$ & $0.05 \%$ & $0.05 \%$ & $0.05 \%$ & $0.05 \%$ & - \\
\hline $\mathrm{RuO}_{2}$ & $0.13 \%$ & $0.13 \%$ & $0.13 \%$ & $0.13 \%$ & $0.03 \%$ \\
\hline $\mathrm{SO}_{3}$ & $0.28 \%$ & $0.00 \%$ & $0.00 \%$ & $0.00 \%$ & $0.05 \%$ \\
\hline $\mathrm{Sb}_{2} \mathrm{O}_{3}$ & - & - & - & - & - \\
\hline $\mathrm{SeO}_{2}$ & - & - & - & - & - \\
\hline $\mathrm{SiO}_{2}$ & $33.00 \%$ & $53.10 \%$ & $43.56 \%$ & $37.43 \%$ & $44.37 \%$ \\
\hline $\mathrm{SnO}_{2}$ & - & - & - & - & - \\
\hline $\mathrm{SrO}$ & $10.29 \%$ & $0.00 \%$ & $0.00 \%$ & $0.00 \%$ & - \\
\hline $\mathrm{TeO}_{2}$ & - & - & - & - & - \\
\hline $\mathrm{ThO}_{2}$ & $5.94 \%$ & $0.00 \%$ & $5.94 \%$ & $0.00 \%$ & - \\
\hline $\mathrm{TiO}_{2}$ & $1.00 \%$ & $0.00 \%$ & $1.00 \%$ & $0.00 \%$ & $0.04 \%$ \\
\hline $\mathrm{Tl}_{2} \mathrm{O}$ & - & - & - & - & - \\
\hline $\mathrm{UO}_{3}$ & $0.00 \%$ & $6.50 \%$ & $0.00 \%$ & $0.00 \%$ & - \\
\hline $\mathrm{V}_{2} \mathrm{O}_{5}$ & - & - & - & - & - \\
\hline $\mathrm{ZnO}$ & $4.00 \%$ & $4.00 \%$ & $0.00 \%$ & $0.00 \%$ & $0.03 \%$ \\
\hline $\mathrm{ZrO}_{2}$ & $0.00 \%$ & $11.50 \%$ & $11.50 \%$ & $0.00 \%$ & $5.43 \%$ \\
\hline TOTAL & $100.0 \%$ & $100.0 \%$ & $100.0 \%$ & $100.0 \%$ & $100.0 \%$ \\
\hline
\end{tabular}

(a) — indicates empty data field.

(b) A value of $0.00 \%$ indicates that the oxide is part of the matrix design but the oxide is absent from the selected glass. 
The Catholic University of America Vitreous State Laboratory
ORP-56325, Rev. 0 Sulfate Solubility in RPP-WTP HLW Glasses Final Report, VSL-06R6780-1, Rev. 0

Table 3.3. Sulfate Solubility in HLW Glasses.

\begin{tabular}{|c|c|c|}
\hline Glass ID & $\begin{array}{c}\text { Sulfate Solubility } \\
\text { (wt\% SO } \text { in Glass) } \\
\text { by Gas Bubbling }\end{array}$ & $\begin{array}{c}\text { Sulfate Solubility } \\
\text { (wt\% } \text { SO }_{3} \text { in Glass) } \\
\text { by Over-Saturation } \\
\text { Melting }\end{array}$ \\
\hline \hline HLW98-77 & $0.58 \%$ & $0.38 \%$ \\
\hline HLW98-86 & $0.73 \%$ & - (a) \\
\hline HLW98-96 & $0.54 \%$ & - \\
\hline HLW02-15 & $0.83 \%$ & - \\
\hline HLW02-22 & $0.60 \%$ & - \\
\hline HLW02-24 & $0.58 \%$ & - \\
\hline HLW02-26 & $0.61 \%$ & - \\
\hline HLW02-43 & $0.82 \%$ & - \\
\hline HLW02-46 & $0.53 \%$ & - \\
\hline HLW02-50 & $0.59 \%$ & - \\
\hline HLW03-01 & $1.12 \%$ & - \\
\hline HLW03-03 & $0.63 \%$ & - \\
\hline HLW04-07 & $0.62 \%$ & - \\
\hline HLW06-16 & $0.84 \%$ & - \\
\hline HLW06-22 & $1.60 \%$ & - \\
\hline HLW06-24 & $0.65 \%$ & - \\
\hline HLW06-27 & $0.64 \%$ & - \\
\hline HLW06-29 & $0.72 \%$ & - \\
\hline HLW06-32 & $0.85 \%$ & - \\
\hline HLW-ALG-03 & $0.87 \%$ & - \\
\hline
\end{tabular}

(a) — indicates testing was not performed. 
The Catholic University of America Vitreous State Laboratory
ORP-56325, Rev. 0

Sulfate Solubility in RPP-WTP HLW Glasses

Final Report, VSL-06R6780-1, Rev. 0

Table 3.4. Analytical Data of the Sulfate Salt Phases that Resulted from Over-Saturation of HLW Glasses (Data presented as oxides for comparison with glass compositions).

\begin{tabular}{|c|c|c|c|c|c|}
\hline Oxide & HLW98-77 & HLW98-86 & HLW98-96 & HLW02-15 & HLW02-22 \\
\hline $\mathbf{A l}_{2} \mathbf{O}_{3}$ & $0.05 \%$ & $0.02 \%$ & $0.04 \%$ & $0.03 \%$ & $0.04 \%$ \\
\hline $\mathbf{B}_{2} \mathbf{O}_{3}$ & $0.48 \%$ & $0.47 \%$ & $0.88 \%$ & $0.58 \%$ & $0.47 \%$ \\
\hline $\mathrm{BaO}$ & $0.01 \%$ & $0.08 \%$ & $0.01 \%$ & $1.35 \%$ & $0.26 \%$ \\
\hline $\mathrm{CaO}$ & $1.35 \%$ & $0.99 \%$ & $1.04 \%$ & $1.55 \%$ & $2.83 \%$ \\
\hline $\mathrm{Cr}_{2} \mathrm{O}_{3}$ & $0.00 \%$ & $0.13 \%$ & $0.15 \%$ & $0.08 \%$ & $0.02 \%$ \\
\hline $\mathrm{Fe}_{2} \mathrm{O}_{3}$ & $0.07 \%$ & $0.00 \%$ & $0.07 \%$ & $0.02 \%$ & $0.06 \%$ \\
\hline $\mathbf{K}_{2} \mathbf{O}$ & $0.18 \%$ & $0.16 \%$ & $0.13 \%$ & $0.30 \%$ & $0.20 \%$ \\
\hline $\mathbf{L i}_{2} \mathbf{O}$ & $9.14 \%$ & $7.05 \%$ & $7.45 \%$ & $4.98 \%$ & $16.84 \%$ \\
\hline MgO & $0.07 \%$ & $0.24 \%$ & $0.00 \%$ & $0.04 \%$ & $0.10 \%$ \\
\hline MnO & $0.06 \%$ & $0.53 \%$ & $0.14 \%$ & $0.93 \%$ & $0.01 \%$ \\
\hline $\mathrm{Na}_{2} \mathrm{O}$ & $25.13 \%$ & $25.65 \%$ & $27.57 \%$ & $30.66 \%$ & $10.90 \%$ \\
\hline $\mathrm{NiO}$ & $0.04 \%$ & $0.00 \%$ & $0.01 \%$ & $0.00 \%$ & $0.01 \%$ \\
\hline $\mathbf{P}_{2} \mathbf{O}_{5}$ & $0.08 \%$ & $0.00 \%$ & $0.00 \%$ & $0.07 \%$ & $1.55 \%$ \\
\hline PbO & $0.02 \%$ & $0.04 \%$ & $0.02 \%$ & $0.08 \%$ & $0.03 \%$ \\
\hline $\mathrm{SiO}_{2}$ & $0.16 \%$ & $0.17 \%$ & $0.27 \%$ & $0.12 \%$ & $0.12 \%$ \\
\hline $\mathrm{SO}_{3}$ & $62.78 \%$ & $61.15 \%$ & $62.08 \%$ & $59.12 \%$ & $65.85 \%$ \\
\hline SrO & $0.19 \%$ & $3.25 \%$ & $0.03 \%$ & $0.03 \%$ & $0.64 \%$ \\
\hline $\mathrm{ZnO}$ & $0.00 \%$ & $0.05 \%$ & $0.04 \%$ & $0.08 \%$ & $0.11 \%$ \\
\hline $\mathrm{ZrO}_{2}$ & $0.13 \%$ & $0.00 \%$ & $0.03 \%$ & $0.00 \%$ & $0.00 \%$ \\
\hline
\end{tabular}


The Catholic University of America Vitreous State Laboratory
ORP-56325, Rev. 0

Sulfate Solubility in RPP-WTP HLW Glasses

Final Report, VSL-06R6780-1, Rev. 0

Table 3.4. Analytical Data of the Sulfate Salt Phases that Resulted from Over-Saturation of HLW Glasses (Data presented as oxides for comparison with glass compositions) (continued).

\begin{tabular}{|c|c|c|c|c|c|}
\hline Oxide & HLW02-24 & HLW02-26 & HLW02-43 & HLW02-46 & HLW02-50 \\
\hline $\mathbf{A l}_{2} \mathbf{O}_{3}$ & $0.04 \%$ & $0.03 \%$ & $0.11 \%$ & $0.34 \%$ & $0.04 \%$ \\
\hline $\mathbf{B}_{2} \mathbf{O}_{3}$ & $0.39 \%$ & $0.40 \%$ & $0.83 \%$ & $0.81 \%$ & $0.40 \%$ \\
\hline $\mathbf{B a O}$ & $0.88 \%$ & $0.70 \%$ & $0.37 \%$ & $0.36 \%$ & $0.45 \%$ \\
\hline $\mathrm{CaO}$ & $0.74 \%$ & $0.42 \%$ & $0.76 \%$ & $1.15 \%$ & $2.01 \%$ \\
\hline $\mathrm{Cr}_{2} \mathrm{O}_{3}$ & $0.38 \%$ & $0.52 \%$ & $0.06 \%$ & $0.07 \%$ & $0.03 \%$ \\
\hline $\mathrm{Fe}_{2} \mathrm{O}_{3}$ & $0.05 \%$ & $0.03 \%$ & $0.03 \%$ & $0.53 \%$ & $0.06 \%$ \\
\hline $\mathbf{K}_{2} \mathbf{O}$ & $0.25 \%$ & $0.28 \%$ & $0.34 \%$ & $0.26 \%$ & $0.30 \%$ \\
\hline $\mathbf{L i}_{2} \mathbf{O}$ & $3.96 \%$ & $2.84 \%$ & $4.58 \%$ & $8.04 \%$ & $6.78 \%$ \\
\hline MgO & $0.02 \%$ & $0.01 \%$ & $0.02 \%$ & $0.03 \%$ & $0.06 \%$ \\
\hline MnO & $0.37 \%$ & $0.18 \%$ & $0.26 \%$ & $0.56 \%$ & $0.44 \%$ \\
\hline $\mathrm{Na}_{2} \mathrm{O}$ & $25.36 \%$ & $30.58 \%$ & $27.42 \%$ & $22.06 \%$ & $23.52 \%$ \\
\hline $\mathrm{NiO}$ & $0.00 \%$ & $0.00 \%$ & $0.00 \%$ & $0.05 \%$ & $0.01 \%$ \\
\hline $\mathbf{P}_{2} \mathbf{O}_{5}$ & $0.59 \%$ & $0.34 \%$ & $0.29 \%$ & $0.47 \%$ & $0.18 \%$ \\
\hline PbO & $0.06 \%$ & $0.06 \%$ & $0.04 \%$ & $0.05 \%$ & $0.06 \%$ \\
\hline $\mathrm{SiO}_{2}$ & $0.22 \%$ & $0.08 \%$ & $0.41 \%$ & $2.07 \%$ & $0.14 \%$ \\
\hline $\mathrm{SO}_{3}$ & $56.37 \%$ & $57.59 \%$ & $57.11 \%$ & $58.34 \%$ & $58.73 \%$ \\
\hline SrO & $10.14 \%$ & $5.81 \%$ & $7.13 \%$ & $4.46 \%$ & $6.45 \%$ \\
\hline $\mathrm{ZnO}$ & $0.03 \%$ & $0.02 \%$ & $0.05 \%$ & $0.12 \%$ & $0.11 \%$ \\
\hline $\mathrm{ZrO}_{2}$ & $0.00 \%$ & $0.00 \%$ & $0.02 \%$ & $0.12 \%$ & $0.01 \%$ \\
\hline
\end{tabular}


The Catholic University of America Vitreous State Laboratory
ORP-56325, Rev. 0

Sulfate Solubility in RPP-WTP HLW Glasses

Final Report, VSL-06R6780-1, Rev. 0

Table 3.4. Analytical Data of the Sulfate Salt Phases that Resulted from Over-Saturation of HLW Glasses (Data presented as oxides for comparison with glass compositions) (continued).

\begin{tabular}{|c|c|c|c|c|c|}
\hline Oxide & HLW03-01 & HLW03-03 & HLW04-07 & HLW06-16 & HLW06-22 \\
\hline $\mathbf{A l}_{2} \mathbf{O}_{3}$ & $0.15 \%$ & $0.04 \%$ & $0.06 \%$ & $0.05 \%$ & $0.06 \%$ \\
\hline $\mathbf{B}_{2} \mathbf{O}_{3}$ & $0.39 \%$ & $0.39 \%$ & $0.56 \%$ & $0.94 \%$ & $1.74 \%$ \\
\hline $\mathbf{B a O}$ & $1.34 \%$ & $0.39 \%$ & $0.37 \%$ & $0.13 \%$ & $0.50 \%$ \\
\hline $\mathrm{CaO}$ & $1.66 \%$ & $0.37 \%$ & $1.44 \%$ & $0.13 \%$ & $0.03 \%$ \\
\hline $\mathrm{Cr}_{2} \mathrm{O}_{3}$ & $0.00 \%$ & $0.19 \%$ & $0.14 \%$ & $1.33 \%$ & $1.61 \%$ \\
\hline $\mathrm{Fe}_{2} \mathrm{O}_{3}$ & $0.14 \%$ & $0.03 \%$ & $0.08 \%$ & $0.04 \%$ & $0.07 \%$ \\
\hline $\mathbf{K}_{2} \mathbf{O}$ & $0.35 \%$ & $0.40 \%$ & $0.17 \%$ & $1.33 \%$ & $0.16 \%$ \\
\hline $\mathbf{L i}_{2} \mathbf{O}$ & $16.10 \%$ & $3.95 \%$ & $6.35 \%$ & $3.45 \%$ & $8.57 \%$ \\
\hline MgO & $0.08 \%$ & $0.01 \%$ & $0.06 \%$ & $0.01 \%$ & $0.01 \%$ \\
\hline MnO & $1.52 \%$ & $0.17 \%$ & $0.60 \%$ & $0.03 \%$ & $0.00 \%$ \\
\hline $\mathrm{Na}_{2} \mathrm{O}$ & $11.67 \%$ & $26.09 \%$ & $28.34 \%$ & $33.63 \%$ & $13.92 \%$ \\
\hline $\mathrm{NiO}$ & $0.00 \%$ & $0.00 \%$ & $0.02 \%$ & $0.01 \%$ & $0.00 \%$ \\
\hline $\mathbf{P}_{2} \mathbf{O}_{5}$ & $0.30 \%$ & $0.48 \%$ & $0.43 \%$ & $0.67 \%$ & $1.08 \%$ \\
\hline PbO & $0.15 \%$ & $0.07 \%$ & $0.13 \%$ & $0.00 \%$ & $0.06 \%$ \\
\hline $\mathrm{SiO}_{2}$ & $0.41 \%$ & $0.12 \%$ & $0.13 \%$ & $0.17 \%$ & $0.38 \%$ \\
\hline $\mathrm{SO}_{3}$ & $65.41 \%$ & $57.22 \%$ & $60.24 \%$ & $56.79 \%$ & $53.69 \%$ \\
\hline SrO & $0.10 \%$ & $9.86 \%$ & $0.85 \%$ & $1.20 \%$ & $17.50 \%$ \\
\hline $\mathrm{ZnO}$ & $0.16 \%$ & $0.01 \%$ & $0.04 \%$ & $0.02 \%$ & $0.00 \%$ \\
\hline $\mathrm{ZrO}_{2}$ & $0.05 \%$ & $0.00 \%$ & $0.00 \%$ & $0.01 \%$ & $0.01 \%$ \\
\hline
\end{tabular}


The Catholic University of America Vitreous State Laboratory
ORP-56325, Rev. 0

Sulfate Solubility in RPP-WTP HLW Glasses

Final Report, VSL-06R6780-1, Rev. 0

Table 3.4. Analytical Data of the Sulfate Salt Phases that Resulted from Over-Saturation of HLW Glasses (Data presented as oxides for comparison with glass compositions) (continued).

\begin{tabular}{|c|c|c|c|c|c|}
\hline Oxide & HLW06-24 & HLW06-27 & HLW06-29 & HLW06-32 & HLW-ALG-03 \\
\hline $\mathbf{A l}_{2} \mathbf{O}_{3}$ & $0.01 \%$ & $0.09 \%$ & $0.03 \%$ & $0.13 \%$ & $0.03 \%$ \\
\hline $\mathbf{B}_{2} \mathbf{O}_{3}$ & $0.55 \%$ & $0.79 \%$ & $0.35 \%$ & $1.93 \%$ & $1.12 \%$ \\
\hline $\mathrm{BaO}$ & $0.67 \%$ & $0.02 \%$ & $1.18 \%$ & $0.00 \%$ & $0.06 \%$ \\
\hline $\mathbf{C a O}$ & $0.56 \%$ & $0.11 \%$ & $1.53 \%$ & $0.03 \%$ & $0.20 \%$ \\
\hline $\mathrm{Cr}_{2} \mathrm{O}_{3}$ & $0.01 \%$ & $0.01 \%$ & $0.01 \%$ & $1.22 \%$ & $1.18 \%$ \\
\hline $\mathrm{Fe}_{2} \mathrm{O}_{3}$ & $0.03 \%$ & $0.14 \%$ & $0.09 \%$ & $0.42 \%$ & $0.03 \%$ \\
\hline $\mathbf{K}_{2} \mathbf{O}$ & $3.94 \%$ & $0.29 \%$ & $5.16 \%$ & $0.14 \%$ & $0.51 \%$ \\
\hline $\mathbf{L i}_{2} \mathbf{O}$ & $0.03 \%$ & $17.06 \%$ & $13.83 \%$ & $0.03 \%$ & $3.83 \%$ \\
\hline MgO & $0.05 \%$ & $0.01 \%$ & $0.19 \%$ & $0.01 \%$ & $0.01 \%$ \\
\hline MnO & $0.00 \%$ & $0.04 \%$ & $0.00 \%$ & $0.55 \%$ & $0.04 \%$ \\
\hline $\mathrm{Na}_{2} \mathrm{O}$ & $30.06 \%$ & $11.89 \%$ & $11.94 \%$ & $38.71 \%$ & $34.50 \%$ \\
\hline $\mathrm{NiO}$ & $0.00 \%$ & $0.01 \%$ & $0.00 \%$ & $0.00 \%$ & $0.00 \%$ \\
\hline $\mathbf{P}_{2} \mathbf{O}_{5}$ & $0.54 \%$ & $1.05 \%$ & $0.74 \%$ & $0.32 \%$ & $0.12 \%$ \\
\hline PbO & $0.07 \%$ & $0.00 \%$ & $0.08 \%$ & $0.00 \%$ & $0.01 \%$ \\
\hline $\mathrm{SiO}_{2}$ & $0.10 \%$ & $0.63 \%$ & $0.31 \%$ & $1.16 \%$ & $0.11 \%$ \\
\hline $\mathrm{SO}_{3}$ & $54.48 \%$ & $67.12 \%$ & $64.47 \%$ & $55.30 \%$ & $58.26 \%$ \\
\hline SrO & $8.71 \%$ & $0.16 \%$ & $0.07 \%$ & $0.03 \%$ & $0.02 \%$ \\
\hline $\mathrm{ZnO}$ & $0.02 \%$ & $0.15 \%$ & $0.00 \%$ & $0.00 \%$ & $0.00 \%$ \\
\hline $\mathrm{ZrO}_{2}$ & $0.01 \%$ & $0.09 \%$ & $0.02 \%$ & $0.01 \%$ & $0.00 \%$ \\
\hline
\end{tabular}


Table 3.5. Density and Melting Point of Selected Sulfate Salts.

\begin{tabular}{|c|c|c|}
\hline Sulfate Salt & Density (g/ml) & Melting Point $\left({ }^{\circ} \mathbf{C}\right)^{(\mathbf{b})}$ \\
\hline $\mathrm{Li}_{2} \mathrm{SO}_{4}$ & 2.221 & 859 \\
\hline $\mathrm{Na}_{2} \mathrm{SO}_{4}$ & 2.664 & 884 \\
\hline $\mathrm{K}_{2} \mathrm{SO}_{4}$ & 2.66 & 1074 \\
\hline $\mathrm{CaSO}_{4}$ & 2.96 & 1400 \\
\hline $\mathrm{SrSO}_{4}$ & 3.96 & 1605 \\
\hline
\end{tabular}

(a) Room temperature density from P. Patnaik, Handbook of Inorganic Chemicals, McGraw Hill, New York, 2003.

(b) From G. J. Janz, Molten Salts Handbook, Academic Press, New York, 1967. 
The Catholic University of America Vitreous State Laboratory
ORP-56325, Rev. 0 Sulfate Solubility in RPP-WTP HLW Glasses Final Report, VSL-06R6780-1, Rev. 0

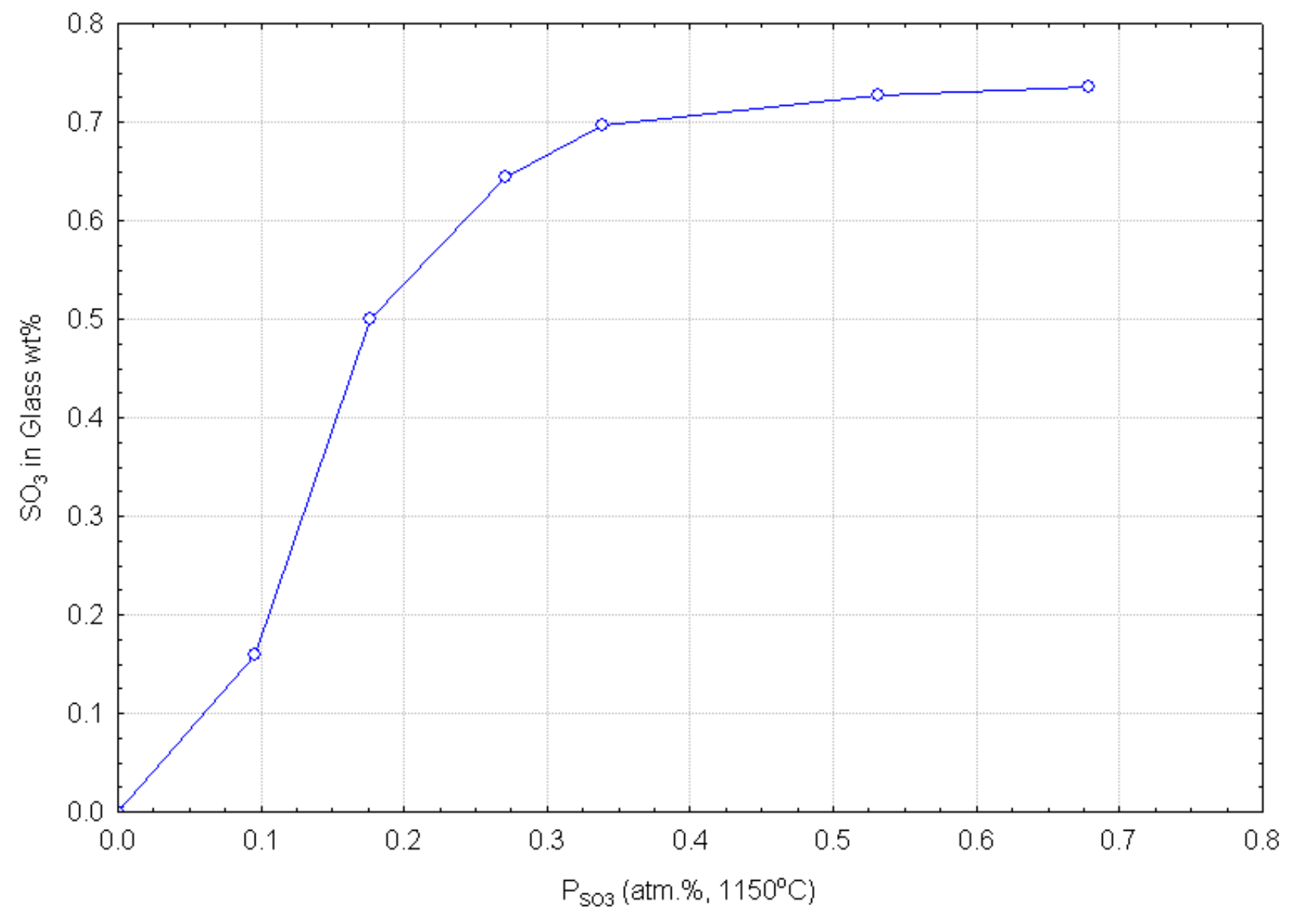

Figure 3.1. Development of Saturation Plateau as the Glass Melt (HLW98-86) is Saturated with Sulfate. 
The Catholic University of America Vitreous State Laboratory
ORP-56325, Rev. 0 Sulfate Solubility in RPP-WTP HLW Glasses Final Report, VSL-06R6780-1, Rev. 0

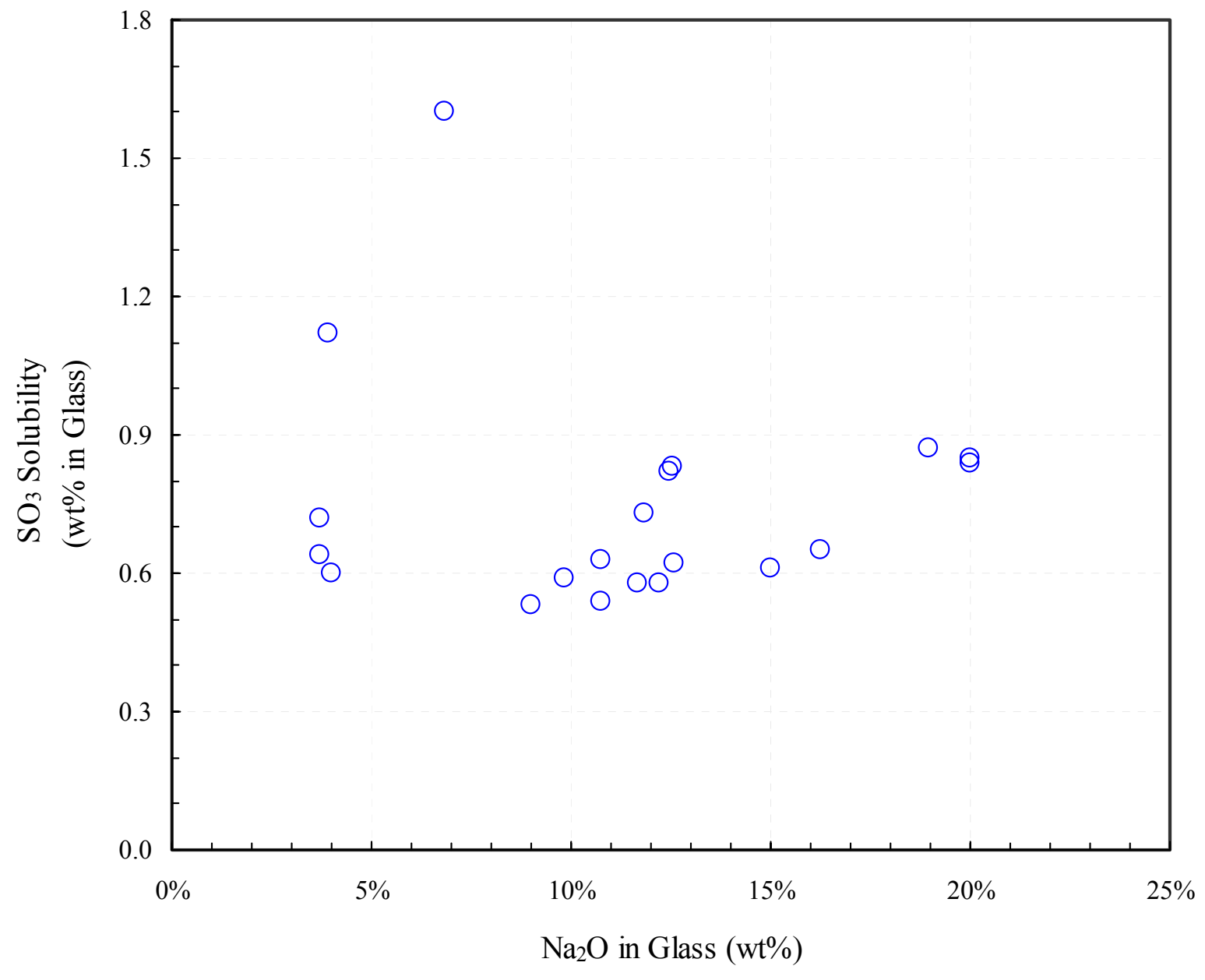

Figure 3.2. Sulfate Solubility in $\mathrm{HLW}$ Glasses as a Function of $\mathrm{Na}_{2} \mathrm{O}$ in Glass. 


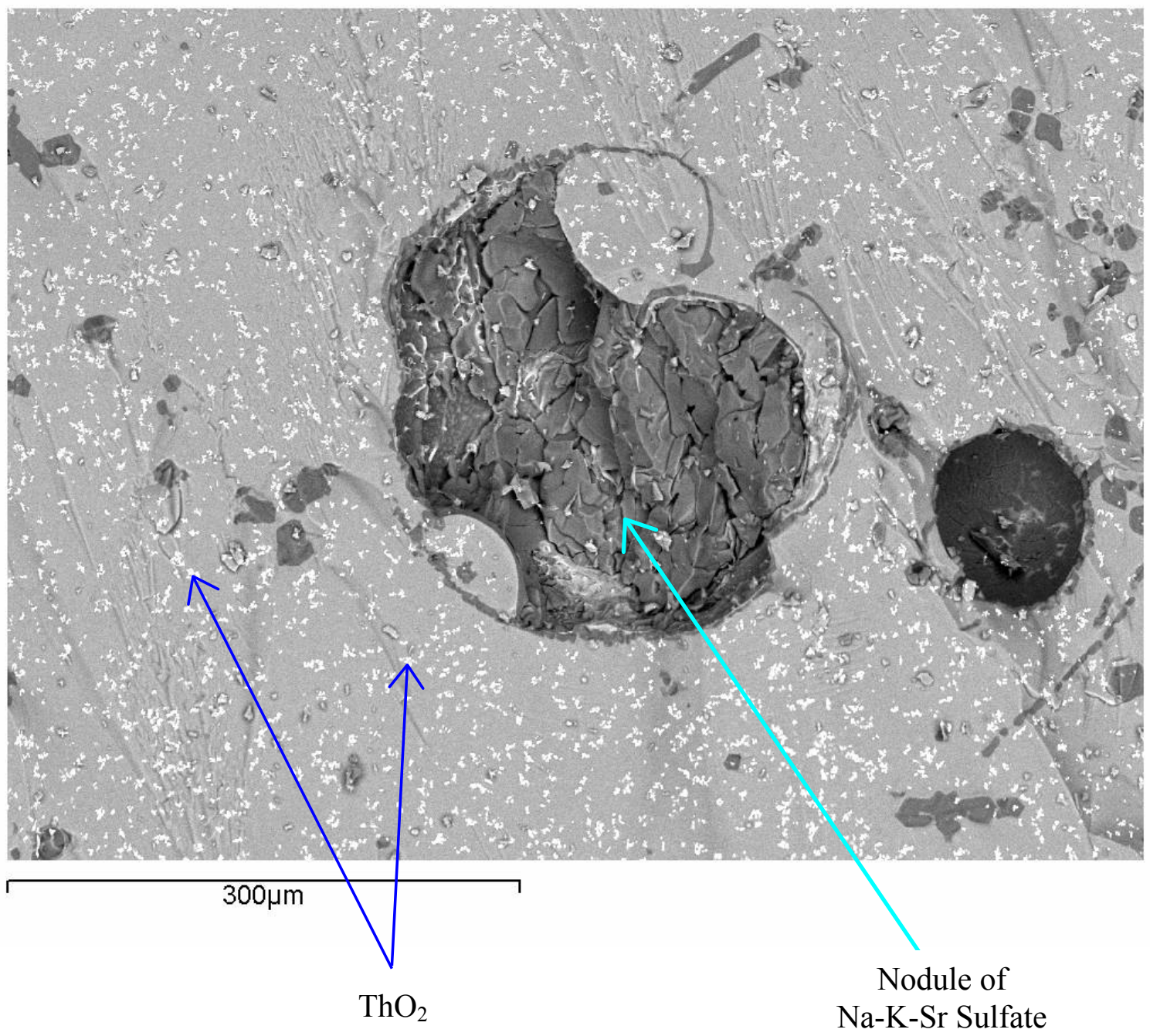

Figure 3.3. Scanning Electron Micrograph of an Inclusion that Developed and Segregated Inside HLW Glass (HLW06-24) after Bubbling Experiment. 